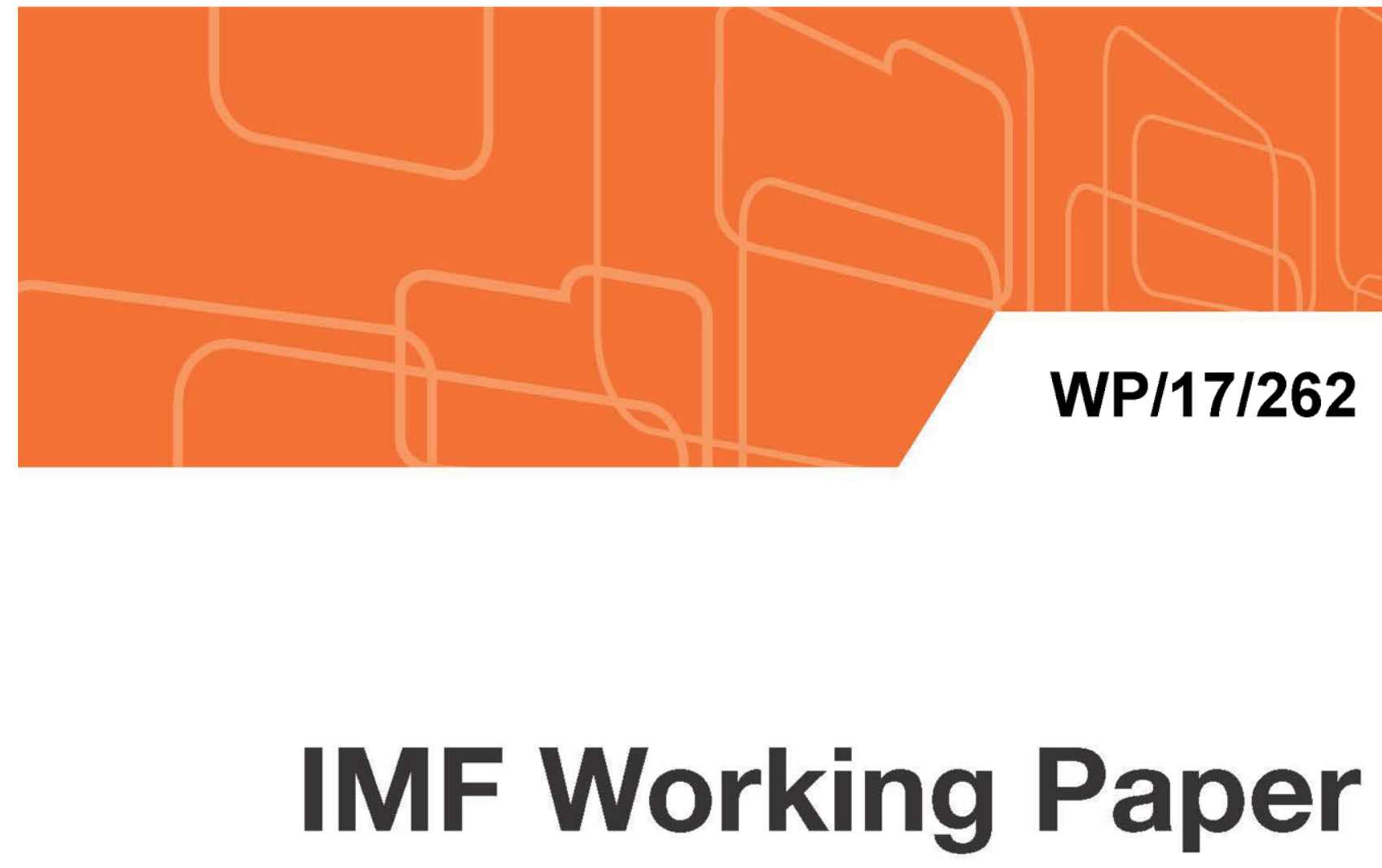

\title{
Winning Connections? Special Interests and the Sale of Failed Banks
}

by Deniz Igan, Thomas Lambert, Wolf Wagner, Quxian Zhang

IMF Working Papers describe research in progress by the author(s) and are published to elicit comments and to encourage debate. The views expressed in IMF Working Papers are those of the author(s) and do not necessarily represent the views of the IMF, its Executive Board, or IMF management.

$$
\text { I N T E R N A T I O N A L M O N E T A R Y F U N D }
$$




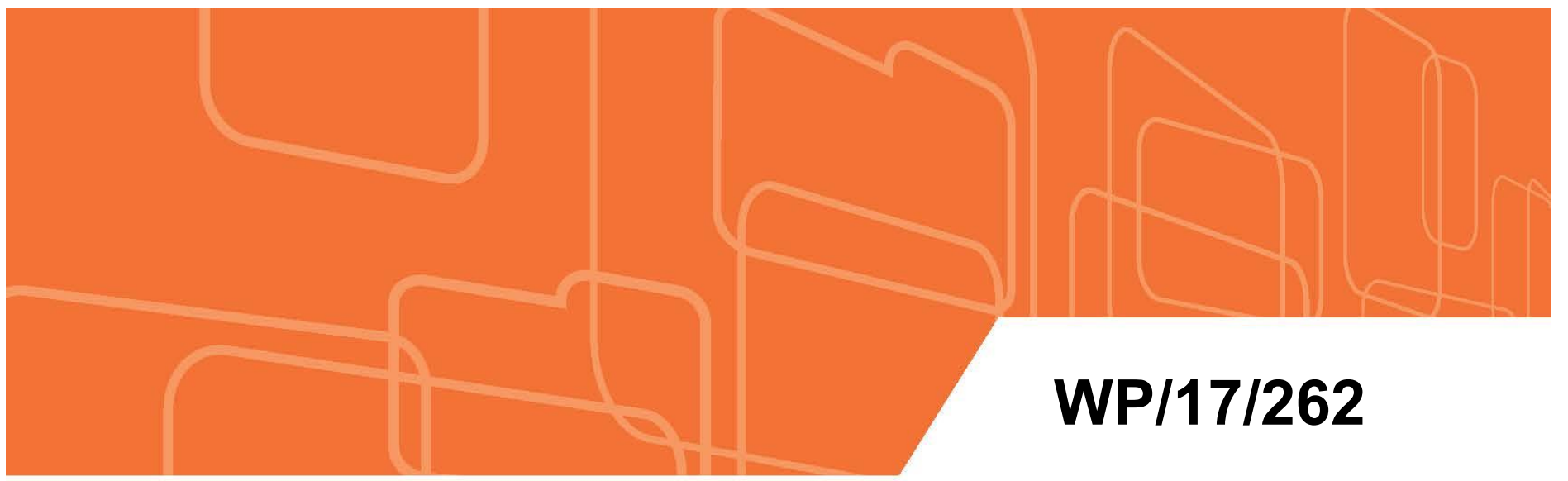

\section{IMF Working Paper}

\section{Winning Connections? \\ Special Interests and the Sale of Failed Banks}

by Deniz Igan, Thomas Lambert, Wolf Wagner, Quxian Zhang

IMF Working Papers describe research in progress by the author(s) and are published to elicit comments and to encourage debate. The views expressed in IMF Working Papers are those of the author(s) and do not necessarily represent the views of the IMF, its Executive Board, or IMF management.

$$
\text { I N T E R N A T I O N A L M O N E T A R Y F U N D }
$$




\title{
IMF Working Paper
}

Research Department

\section{Winning Connections? Special Interests and the Sale of Failed Banks}

\author{
Prepared by Deniz Igan, Thomas Lambert, Wolf Wagner, Quxian Zhang*
}

Authorized for distribution by Maria Soledad Martinez Peria

November 2017

\begin{abstract}
IMF Working Papers describe research in progress by the author(s) and are published to elicit comments and to encourage debate. The views expressed in IMF Working Papers are those of the author(s) and do not necessarily represent the views of the IMF, its Executive Board, or IMF management.
\end{abstract}

\begin{abstract}
We study how lobbying affects the resolution of failed banks, using a sample of FDIC auctions between 2007 and 2014. We show that bidding banks that lobby regulators have a higher probability of winning an auction. In addition, the FDIC incurs higher costs in such auctions, amounting to 16.4 percent of the total resolution losses. We also find that lobbying winners have worse operating and stock market performance than their non-lobbying counterparts, suggesting that lobbying results in a less efficient allocation of failed banks. Our results provide new insights into the bank resolution process and the role of special interests.
\end{abstract}

JEL Classification Numbers: D72, E65, G18, G21

Keywords: Bank resolution, Failed banks, Financial crisis, Lobbying, Rent seeking

Authors’ E-Mail Addresses: digan@,imf.org; t.lambert@rsm.nl; wagner@,rsm.nl; eden.zhang@monash.edu

\footnotetext{
${ }^{*}$ Lambert and Wagner are from Rotterdam School of Management, Erasmus University. Zhang is from Monash Business School, Monash University. We thank Nicola Babarcich, Santanu Kundu, and Huy Nguyen for excellent research assistance. Comments and suggestions from Eric de Bodt, Stephen Brown, Jean-Edouard Colliard, Zhanhui Chen, Giovanni Dell'Ariccia, Enrica Detragiache, Bob DeYoung, Andrew Ellul, Iş11 Erel, Ümit Gürün, Sole MartinezPeria, Louis Nguyen (discussant), Sharyn O'Halloran (discussant), Marcelo Pinheiro, Karla Vasquez-Suarez, Guillaume Vuillemey (discussant), David Yermack, and participants at seminars at the Banque de France-ACPR, Erasmus University, IESEG School of Management, Koç University, Monash University, University of Bonn, University of Lille, University Paris-Dauphine, and at the 2017 Banking and Financial Intermediation Workshop in Bristol, the 2017 Public Authority and Finance Conference in Paris, the 2017 EFI Network Workshop in Brussels, and the 2017 FIRN Annual Conference in Uluru are gratefully acknowledged. All errors are our own.
} 


\section{Contents}

Abstract tow-1.1.

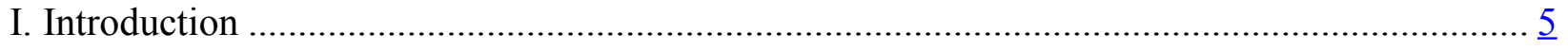

II. Institutional Background and Data...........................................................................

A. An Overview of the FDIC Resolution and Receivership Process ........................................ $\underline{8}$

B. Bank Lobbying Activities in the United States ................................................................... 10

C. Sample Composition, Data Sources, and Key Variables ………………………………. 12

D. Descriptive Statistics ............................................................................................. 13

III. Empirical Results on Failed-Bank Auctions and Bidder Lobbying...................................... 14

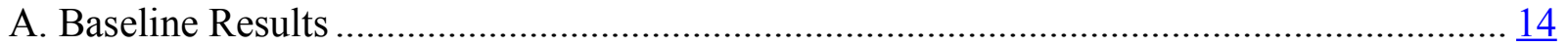

B. Instrumental Variable Results ............................................................................... 16

C. Alternative Lobbying Measures …………………………………………………... 17

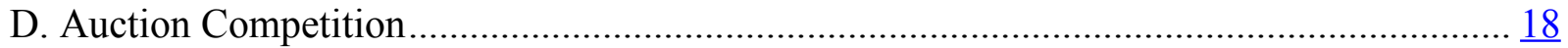

IV. Assessing the (Mis)allocation of Failed Banks due to Lobbying .......................................... 19

A. Acquirers' Bids and Resolution Costs ...................................................................... 19

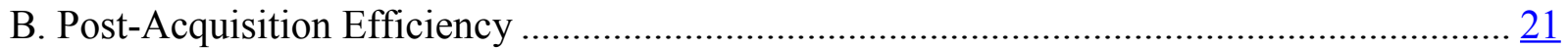

C. Are Lobbying Bidders Engaged in Rent Seeking? A Discussion …………………........... 22

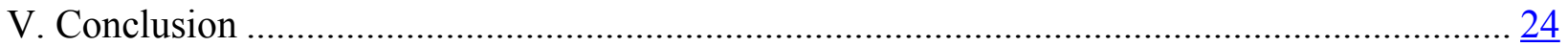

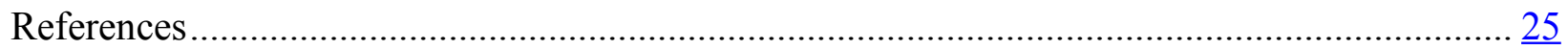

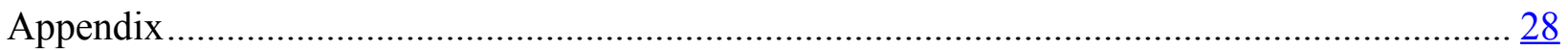

List of Figures

Figure 1. Aggregated Lobbying Expenditures by Banks Satisfying the FDIC Initial Criteria..... $\underline{31}$

Figure 2. Number of Bank Failures .......................................................................... 32

Figure 3. Bidder Lobbying Activities around Bank Failures.................................................... $\underline{33}$

Figure 4. Histogram of Failed Bank Assets ...................................................................... $\underline{34}$

Figure 5. Kernel Density of Failed Bank Assets and Resolution Costs....................................... $\underline{35}$

Figure 6. Bidder Abnormal Returns..................................................................................... $\underline{36}$

List of Tables

Table 1. Auction Sample Construction ..................................................................................

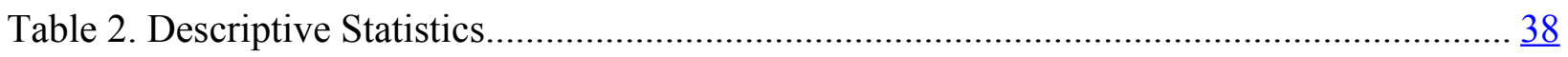

Table 3. Winning and Losing Bidders ............................................................................. 40 
Table 4. Auction Winning Likelihood and Bidder Lobbying: Baseline Results .....

Table 5. Auction Winning Likelihood and Bidder Lobbying: Instrumental Variable Results ..... $\underline{42}$

Table 6. Auction Winning Likelihood and Bidder Lobbying: Alternative Lobbying Measures .. $\underline{43}$

Table 7. Auction Winning Likelihood and Bidder Lobbying: Auction Competition.................. 44

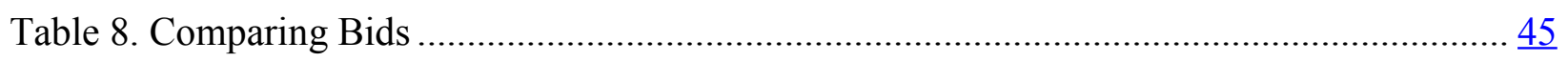

Table 9. Post-Acquisition Efficiency ........................................................................... 46

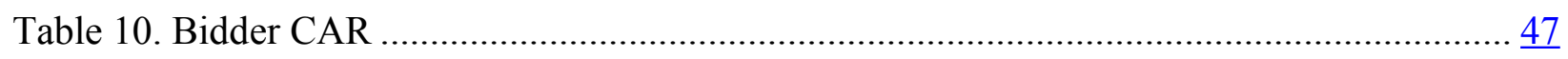




\section{INTRODUCTION}

In order to safeguard financial stability, regulators are endowed with special powers and typically enjoy broad discretion in exercising them. The aftermath of the financial crisis has, however, put forth failures and gaps in regulatory actions. In particular, regulators have been criticized for serving special interests - not only of the banks they regulate but also their own - rather than the interest of the general public (McCarty, Poole, and Rosenthal, 2013; Admati and Hellwig, 2014). ${ }^{1}$ The resolution of failed banks in the United States is an important case in point. The Federal Deposit Insurance Corporation (FDIC) is tasked to efficiently handle bank failures and, to do so, is empowered to act independently, without interference from other agencies or courts, and to use its own discretion. However, this also raises concerns about transparency and fairness in the resolution process (Morrison, 2010).

In this paper, we study how special interests, through lobbying by banks, affect the efficiency of bank resolution carried out by the FDIC. Lobbying may introduce private interests into the decision-making process and distort regulatory decisions through influence. However, it can also provide the FDIC with useful private information, making the resolution process more efficient. We use the sale of failed banks as a laboratory for our analysis. The FDIC routinely auctions failed banks to interested bidders. ${ }^{2}$ In an efficient resolution process this should result in ownership being transferred to the bidders that are best equipped to incorporate the new entity and have the highest valuation for it. At the same time, the sale should result in low resolution costs as stipulated by the "least-cost" test that requires the FDIC to seek solutions that minimize the burden on the Deposit Insurance Fund (DIF). ${ }^{3}$

Our analysis is based on detailed information on failed-bank auctions over the period between 2007 and 2014. We first provide clear evidence that bidding banks engaged in lobbying activities are in a better position to win an auction. Bidders lobbying banking regulators and, in particular, the FDIC at the time of the failure increase their probability of winning an auction by 26.4 percentage points. We also find that the effectiveness of lobbying considerably depends on the type of lobbying employed, with the largest effects arising from the usage of revolving-door lobbyists and of lobbying contact with the FDIC. ${ }^{4}$

\footnotetext{
${ }^{1}$ See for example Jo Becker and Gretchen Morgenson, "Geithner, Member and Overseer of Finance Club," New York Times, April 26, 2009.

${ }^{2}$ During 2007-14 the FDIC auctioned off 471 banks (including Washington Mutual) with a combined total balance sheet size of about $\$ 636$ billion, equal to around 5 percent of the size of the FDIC-insured banks in 2010.

${ }^{3}$ There are also potential systemic repercussions in a failed-bank auction, suggesting that a speedy and smooth transfer is of value. However, the average bank in our sample is fairly small, hence systemic arguments are of more limited importance.

${ }^{4}$ These results are robust to the extension of our sample to all prospective bidders (i.e., banks allowed to bid according to the FDIC initial criteria) for each failed-bank auction. Based on a Heckman-probit analysis, we find that lobbying positively impacts on the probability of winning an auction, while it does not affect the propensity of prospective bidders to self-select into an auction.
} 
A potential explanation for our findings, unrelated to special interests, is that a bidder's lobbying activity proxies for the ability to conduct acquisitions, in turn determining the probability of winning. We employ an instrumental variable approach to mitigate such endogeneity concerns, using lobbying activities that are not directed toward banking regulators as an instrument. The motivation is that lobbying entails high barriers to entry (Kerr, Lincoln, and Mishra, 2014; Drutman, 2015); hence a bank already engaged in the lobbying process is better positioned to lobby on a specific banking topic. At the same time, general lobbying unrelated to banking is unlikely to interfere with decisions undertaken by banking regulators and, in particular, the FDIC. We find that the instrumental variable estimates are consistent with our base estimates - both in terms of magnitude and statistical significance.

Next, we study whether lobbying also affects the costs associated with bank failure. For this we compare the actual resolution costs to the costs that the FDIC would have incurred if another bid had been chosen. We show that the cost differential is significantly reduced, and is also more likely to be negative, when acquirers lobby. Lobbying acquirers thus seem to pay less than other bidders. The implied cost to the DIF is substantial. At 16.4 percent of the total resolution losses, it amounts to a total transfer from the DIF to lobbying bidders of $\$ 7.4$ billion.

Besides the auction outcome itself, we also examine the post-acquisition performance of acquirers. In a difference-in-differences setting, we first show evidence consistent with the expectation that acquisition of a failed bank improves efficiency as measured by return on assets and cost-to-asset ratio. However, we find that lobbying acquirers have substantially inferior efficiency outcomes relative to their non-lobbying counterparts. When we study the market response of the bidders surrounding the failed-bank acquisition announcement, we find results consistent with lower efficiency for lobbying acquirer. Their cumulative abnormal returns (CAR) around acquisition announcements are 0.9 percentage points lower, relative to the sample average acquirer CAR of 2.1 percent.

Our results speak to the channel through which special interests affect regulatory outcomes. In principle, there can be two opposing forces: lobbying can result in favorable treatment (rentseeking channel) but can also reveal useful information to regulators (informational channel). Distinguishing between these channels has proven difficult, as discussed by Facchini, Mayda, and Mishra (2011) and Igan and Mishra (2014), among others. Under the rent-seeking channel, the fact that lobbying allows banks to acquire other banks at lower prices suggests an economic misallocation as this may prevent the bank with the highest valuation from winning the auction. The auction results are also consistent with the informational channel: regulators may allocate banks at lower prices to bidders who have conveyed private information that convince the regulators that they are better suited to incorporate the acquired bank. However, the fact that lobbying banks underperform other acquirers appears inconsistent with such an efficiencyimproving role of bank lobbying. Instead, it is consistent with agency-type inefficiencies in the allocation of failed banks predicted by rent-seeking theories à la Shleifer and Vishny (1994).

Taken together, our empirical analysis suggests that, in the context of bank resolution, regulatory discretion may have costs by providing an opening for special interests to influence the process. This, by no means, implies that giving regulators discretion is undesirable - the ability to incorporate private information and to react to new circumstances in a speedy manner provides important benefits for financial stability. Rather, the resolution process should be designed to 
mitigate these costs by ensuring proper checks and balances. Specifically, discretionary powers of the resolution authority should be counterbalanced by a robust governance framework that establishes a strong accountability and transparency mechanism vis-à-vis the public and political bodies. ${ }^{5}$ In this context, our findings are relevant not only for the United States-where a framework for resolution of smaller banks is relatively well established and that for resolution of systemically important financial institutions has recently been reformed-but also for other jurisdictions (e.g., the European Union) where implementation of new comprehensive resolution frameworks is currently in progress (Philippon and Salord, 2017).

Our paper is related to several strands of literature. First, it is part of the literature on the resolution of failed banks, which mostly focused on the savings and loan (S\&L) crisis of the 1980s. James and Wier (1987) study how the setup of the FDIC auction and competition affect the sale price of failed bank assets, and report evidence of wealth transfers to winning bidders. Our findings confirm such wealth transfers and show that, in addition, their magnitude is related to bidders' lobbying activities. In related work, Giliberto and Varaiya (1989) find that winning bids tend to increase with the number of competitors, consistent with the winner's curse hypothesis. James (1991) shows that losses - measured as the difference between the book value of assets and the recovery value net of direct expenses related to the failure - are substantial, averaging 30 percent of the failed bank assets. We observe losses in similar magnitude in our sample.

Another set of studies followed the 2008-09 financial crisis. Granja (2013) finds that regulators incur lower resolution costs when disclosure requirements for failed bank are more comprehensive, suggesting that such requirements help mitigate information asymmetries inherent to the auction process. Cole and White (2017) examine the timing of FDIC receivership and estimate the costs of forbearance to be almost 40 percent of the FDIC's estimated costs of closure ${ }^{6}$ Closer to our line of inquiry, the work by Granja, Matvos, and Seru (2017) document that the wedge between potential acquirers' willingness to pay - as captured by their proximity with the failed bank in terms of location and lines of business - and ability to pay - as proxied by their capitalizationdistorts the allocation of failed banks. The authors conclude that frictions in the sale of failed bank

\footnotetext{
${ }^{5}$ See IMF-WB (2009) and Claessens and Kodres (2014) for details on international standards and best practices for bank insolvency frameworks. Note that, while a high degree of accountability is desirable, how this is accomplished is also important. In particular, in relation to judicial review, international standards recommend that, to ensure speediness and effectiveness of the resolution actions, legal remedies and judicial action are limited in their scope and effects (e.g., review limited to the legality of the resolution actions and prohibiting reversal or annulment of the resolution actions).

${ }^{6}$ Kroszner and Strahan (1996) investigate the role of politics and the incentives of regulators to intervene in failing banks' operations, and provide compelling evidence that regulators deferred the realization of costs in failing S\&L associations (see also Kane, 1989). Also in the United States, Liu and Ngo (2014) show that political concerns play a significant role in the timing of bank failures over the period 1976-2010. Brown and Dinc (2005) find consistent evidence from a sample of large banks in 21 emerging countries, while Imai (2009) examines the case of Japan in 1999-2002. Our paper adopts a different perspective and provides evidence of special interest politics being at play in the resolution of failed banks.
} 
are significant. Our work shows that special interests are another source of distortion in the allocation of banks. ${ }^{7}$

We also contribute to the literature on the political economy of the financial crises. ${ }^{8}$ Mian, Sufi, and Trebbi (2013) show that both special and constituent interests influenced public policy, leading to higher subprime mortgage lending in the years prior to the crisis. Igan and Mishra (2014) document that politically-targeted activities of the financial industry swayed legislators' position toward deregulation between 1999 and 2006. Mian, Sufi, and Trebbi (2010) find that special interest campaign contributions from the financial services industry were positively associated to votes in favor of the Emergency Economic Stabilization Act of 2008, a bill which transferred wealth from taxpayers to the financial services industry (Veronesi and Zingales, 2010). A few studies focus, like we do, on bank lobbying activities. These studies provide evidence that lobbying banks were more likely to be bailed out (Duchin and Sosyura, 2012) and that they were less likely to face enforcement actions (Lambert, 2017), even though they took on more excessive risks in the run-up to the financial crisis (Igan, Mishra, and Tressel, 2012). ${ }^{9}$ Our results suggest that lobbying might not only have an effect prior to bank failure but also affects outcomes post failure. In that sense, our analysis relates to the literature on the optimal resolution of bank failures (Acharya and Yorulmazer, 2007, 2008; Walther and White, 2016).

The rest of the paper is organized as follows. Section II gives information on the institutional background and the data used in the analysis. Section III presents the results of the empirical analysis on bidder lobbying and the probability of winning a FDIC-run auction. Section IV discusses whether the results can be interpreted as a sign of misallocation. Section V concludes.

\section{INSTITUTIONAL BACKGROUND AND DATA}

\section{A. An Overview of the FDIC Resolution and Receivership Process}

The FDIC, together with the other federal agencies - the Federal Reserve (Fed) and the Office of the Comptroller of the Currency (OCC) - and state regulators, supervises banks, but also has the authority to resolve failing or failed institutions. ${ }^{10}$ When a bank is about to fail, the FDIC initiates its resolution process, which formally begins when it receives a notification (the failing bank letter) from the institution's primary regulator. The main reasons for a failure are critical undercapitalization, insolvency, deposit runs, and implication in a severe case of fraud. Upon receiving the notification, the FDIC contacts the management of the failing institution and arranges

\footnotetext{
${ }^{7}$ Therefore, our work is also related to the corporate finance literature on bankruptcy auctions. A partial list in this literature includes: Stromberg (2000), Thorburn (2000), and Eckbo and Thorburn (2008).

${ }^{8}$ See Lambert and Volpin (2017) for a survey of the literature.

${ }^{9}$ This evidence is consistent with other studies that show that banks paying higher fees are subject to more lenient regulation and, in the long run, have more loans defaulting (Kisin and Manela, 2016) and that banks are less likely to fail in the year leading up to a gubernatorial election (Liu and Ngo, 2014).

${ }^{10}$ Note that the regulatory overhaul following the 2008-09 financial crisis, enshrined in the Dodd-Frank Act of 2010, eliminated one of the regulators at the federal level, namely, the Office of Thrift Supervision (OTS). We have banks supervised by the OTS in our sample, given that the data set covers failures between 2007 and 2014.
} 
for specialists to go to the bank to compile information in preparation for the closing. During this on-site visit, the specialists prepare an information package for potential bidders, perform an asset valuation review ${ }^{11}$ (subsequently used to set a reservation value on the sale), estimate the amount of uninsured deposits, determine the resolution method, and plan for the closing and receivership (FDIC, 2014, chapter 3).

Using the information collected on site, the FDIC chooses the most appropriate resolution method to be offered. During the recent crisis, and for most of the FDIC's history, the purchase and assumption (P\&A) transaction has been the preferred resolution method-i.e., in more than 90 percent of cases in our sample period. In a P\&A transaction, a healthy financial institution agrees to purchase some or all of the assets of the failing depository institution and assumes some or all of the liabilities, including all insured deposits. This is performed through a process that resembles a first-price sealed bid auction. Other methods, including deposit payoffs and purchase and assumption of the insured deposits only (PIs), are usually considered by the FDIC when the auction does not attract any interested bidder or when bids revealed to be below its reservation value.

After gathering the necessary information and determining the resolution method, the FDIC starts to confidentially market the failing institution to a group of approved potential bidders. ${ }^{12}$ This initial contact does not contain any identifiable information regarding the distressed institution. Then, a virtual data room - access to which is conditional on signing a confidentiality agreement is set up to provide potential bidders with details of the failing institution (loan review, schedules representing the value of the items on the balance sheet, operational information, legal documents, bidding procedure). If feasible, prospective bidders are also given the opportunity to review these information as part of their on-site due diligence. The FDIC is not required to reveal whom it invites for the bidding.

After having completed due diligence, bidders submit their bids to the FDIC, generally one to two weeks before the scheduled closing. The bidders can place one or more sealed bids for the failed bank. A bid consists of, at least, two pricing terms: the first is the franchise value for the deposits (the premium) and the second is the amount for the assets. An additional element that may compose a bid is the terms of a potential loss-sharing agreement between the FDIC and the bidder over the subsequent losses on the assets transferred in the resolution process. ${ }^{13}$ The FDIC uses its proprietary least-cost test model to evaluate submitted bids and then selects the one, given the reservation value set by the FDIC, that is the least costly for the DIF, as mandated by the Federal Deposit Insurance Corporation Improvement Act of 1991 (FDICIA). The FDIC is, however, not required to disclose the specifics of these tests and, primarily based on systemic considerations,

\footnotetext{
${ }^{11}$ The FDIC may hire contractors to complete this work.

12 The qualifying criteria are the following: (1) be a financial institution or in the process of applying for a bank charter; (2) be well-capitalized; (3) possess a CAMELS rating of 1 or 2; (4) have a satisfactory anti-money-laundering record; (5) have a satisfactory Community Reinvestment Act (CRA) rating; (6) be sufficiently large (i.e., twice the size of the failed institution if located in the same state, even larger otherwise). See also Table A.1 in the appendix.

${ }^{13}$ Under a loss-sharing agreement, the FDIC agrees to absorb a portion of the loss on a specified pool of assets (i.e., commercial assets and residential mortgages), which maximizes asset recoveries and minimizes losses by preventing the FDIC of having to keep or take back large amounts of assets that it would then attempt to sell piecemeal under unfavorable market conditions (for details, see FDIC, 2003, chapter 7; FDIC, 2014, chapter 4).
} 
has recourse to legal exemptions through which it may choose a bid without the least-cost test, thus taking into account unobserved, complex considerations (IMF, 2015). ${ }^{14}$ Arguably, it is especially in these circumstances under which private information is more valuable and public interest appraisal is more complicated that the FDIC exerts most of its discretionary powers.

Once the FDIC board of directors approves the resolution transaction, the final step is the closing of the bank, and the appointing of the FDIC as receiver. Immediately after closure, the FDIC informs the public of the institution's closing, and announces the winning bidder together with an estimate of the cost of resolving the failed institution. The FDIC as receiver is responsible for settling the affairs of the failed institution, which comprises transferring to the acquirer the assets purchased and deposits assumed, and to the extent possible, satisfying the creditor claims against the receivership. An insured depository institution is generally placed in receivership within 90 days, not including the settlement timeframes which can take much longer (Hynes and Walt, 2010). Despite the expedient and orderly resolution of the vast majority of failed banks, the FDIC took a loss on most failures since the beginning of the crisis; the cumulated loss so far adds up to $\$ 75$ billion.

To fulfil this mission as receiver, Congress has entrusted the FDIC with complete responsibility and has also conferred protections and plenary power over the process. ${ }^{15}$ The FDIC is not subject to the direction or supervision of any other executive agency, state, or court in the operation of the receivership, which allows the FDIC to use its discretion in determining the most effective resolution of failed institutions. The most significant of these powers fall into the following categories (FDIC, 2014, chapter 5): (1) determining whether to allow or disallow claims; (2) repudiating contracts that are deemed to be burdensome; (3) placing litigation on hold; (4) avoiding fraudulent conveyances; and (5) using special defenses. The latter point (5), for instance, protects the FDIC by prohibiting courts from issuing injunctions or similar equitable relief to restrain the receiver from completing its resolution or liquidation activities.

\section{B. Bank Lobbying Activities in the United States}

Lobbying is pervasive in the American democratic process (Drutman, 2015) and, in particular, constitutes the bulk of politically-targeted spending aimed at influencing policies and regulatory decisions (Kerr, Lincoln, and Mishra, 2014). Lobbyists attempt to sway the influence of regulators

\footnotetext{
14 Title XI of the Dodd-Frank Act curtailed the systemic risk exception authority of the FDIC. This authority can now only be used for insured depository institutions placed into receivership and wound down and not used for open bank assistance. That said, Title II broadens the resolution powers granted to the FDIC in the resolution of systemically important financial institutions and, specifically, gives it broad discretionary power for selecting the appropriate resolution measures to be taken. Non-systemic banks represent the vast majority of failed banks in our sample. Hence, this seeming loss of discretion is less likely to apply to the cases we study.

15 To protect its independence, the FDIC receives no congressional appropriations and instead is funded by premiums that banks and thrifts pay for deposit insurance coverage and from earnings on investments in U.S. Treasury securities. That said, the five people that form the FDIC board of directors are all appointed by the President and confirmed by the Senate, with no more than three being from the same political party. Bovenzi (2015) provides an account of a longterm account of the interactions of senior supervisory officials, political appointees, elected representatives, and the banking industry.
} 
and politicians on specific issues, using a combination of contacts, expertise, persuasion and public relations skills. Banking interests are particularly well represented by lobbyists, whether external or in-house. In 2009, at the height of the crisis, commercial banks alone spent approximately $\$ 50$ million in hiring lobbyists, which is five times the money they spent on campaign contributions over the same year. Regarding banks that are allowed to bid in an auction (i.e., banks satisfying the qualifying criteria laid out in footnote 11), the amounts spent on lobbying are about four times larger (Figure 1). In 2009, again, lobbyists specifically targeted the FDIC 120 times, and about 800 times between 2007 and 2014. ${ }^{16}$

Legally, a lobbying contact is defined as "any oral or written communication (including an electronic communication) to a covered executive branch official or a covered legislative branch official that is made on behalf of a client with regard to (i) the formulation, modification, or adoption of Federal legislation (including legislative proposals); (ii) the formulation, modification, or adoption of a Federal rule, regulation, Executive order, or any other program, policy, or position of the United States Government; (iii) the administration or execution of a Federal program or policy (including the negotiation, award, or administration of a Federal contract, grant, loan, permit, or license); or (iv) the nomination or confirmation of a person for a position subject to confirmation by the Senate" (Lobbying Disclosure Act [2 U.S.C. 1602]). The definition under (iii) is, in our analysis, the type of activity we are interested in.

The Lobbying Disclosure Act of 1995 (LDA), by bringing a certain level of accountability to federal lobbying practices, imposes lobbyists to register and report periodically information on their activities to the Senate Office of Public Records (SOPR). The information that external and in-house lobbyists have to disclose includes the amount of money they receive by their clients as well as the issues and the officials (at the agency level) targeted. Another feature of the disclosed information is that the identity of lobbyists hired by a particular firm to lobby a particular agency on a particular issue is known. Hence, it is possible to categorize different lobbyists based on their previous work experience. In the literature, a commonly used concept has been that of the "revolving door" whereby former members of Congress, staffers, and public sector employees leave their posts to become lobbyists. ${ }^{17}$

The information available through lobbying disclosure filings helps thus determine the economic motivation behind the lobbying effort, the branch of the government targeted, and lobbyists' past employment at banking regulators. In other words, one can observe which bank hired which lobbyist to contact which agency, allowing a detailed examination of whether bank lobbying activities have a bearing on failed-bank auction outcomes.

\footnotetext{
16 Sourced from www.opensecrets.org (last accessed: May 2017).

${ }^{17}$ Bertrand, Bombardini, and Trebbi (2014) document the importance of the connections built through the revolving door in determining what issues a lobbyist is hired to work on. Blanes i Vidal, Draca, and Fons-Rosen (2012) show that lobbyists who worked for legislators in the past generate more revenue.
} 


\section{Sample Composition, Data Sources, and Key Variables}

Our empirical analysis combines data on each government-assisted deal from SNL Financial and publicly available information released by the FDIC on these deals. ${ }^{18} \mathrm{We}$ obtain from these sources information on the identities of failed banks and acquirers, bidding information, P\&A terms, estimated costs of resolution, and, if available, the identities of other bidders. ${ }^{19}$ The shaded area of Figure 2 shows the time distribution of all failed banks in our sample, while Table 1 presents the construction of the auction sample. From 2007 to 2014, our period of interest, the FDIC acted as the receiver for 522 commercial and savings banks and chose the P\&A transaction as the resolution method in 470 of cases. We drop from our analysis 39 cases without auction disclosures occurring prior to May 2009 as well as the P\&A transaction of Home National Bank, which involved two acquirers. ${ }^{20}$ We exclude assistance transactions (13 cases), direct payoffs (26), and PIs (13), because there are no auction data available. ${ }^{21}$ We end up with a sample composed of 430 P\&A transactions, accounting for $\$ 278.3$ billion of aggregate total assets. Table 1 also reports that 65.8 percent of the FDIC-run auctions attract bids from at least two eligible institutions, out of which 43.1 percent records four or more bidders.

We obtain financial characteristics of both failed and bidding banks from the Quarterly Report on Condition and Income (or Call Report) filings. These Call Reports provide detailed information on the size, capital structure, and asset composition for each commercial and savings bank, while SNL Financial provides further information on bank characteristics and an estimation of banks' CAMELS rating. ${ }^{22}$ Moreover, we compute various measures of bidders' proximity to failed banks using information from the Summary of Deposits database provided by the FDIC.

We use lobbying disclosure filings of SOPR to identify banks that are engaged in lobbying. The version of the data used comes from the Center for Responsive Politics (CRP). ${ }^{23}$ We merge CRP data with the SNL Financial database using a name-matching procedure (i.e., an algorithm that

\footnotetext{
${ }^{18}$ FDIC data are retrieved from www.fdic.gov/bank/individual/failed/banklist.html (last accessed: April 2016).

${ }^{19}$ The FDIC discloses on its website the identities and bidding information of all bidders. Note, however, that we can only obtain the identities of acquirers (winning bidders) and cover bidders (second place). For the remaining bidders, the FDIC provides a list of bidder names without linking to specific bidding information. Nonetheless, we compile the sample of actual bidders including all the bidders disclosed by the FDIC. We match the names of bidder banks with the FDIC institution directory to identify each bidder with a FDIC certification number. For each bidder, we identify several potential matches in the institution directory using fuzzy matching algorithms based on spelling and phonetic distances. Then we go over each matched pair based on bank names, cities, and states to confirm the automated match. For bidder names without a match, we use manual searches to identify a match.

${ }^{20}$ Before that date little was known about other bidders and their bidding prices. From November 2009, the FDIC, in compliance with the Freedom of Information Act (FOIA), began to disclose all the bids in auctions subsequent to May 2009. The information disclosed by the FDIC increased due to the change in the FDIC's internal policy under public pressure. Before the change, one needed to file a FOIA request to obtain such information.

${ }^{21}$ There is also an economic reason to exclude these transactions: the FDIC opted for these resolution methods because there were no potential acquirers.

22 CAMELS - officially, Uniform Financial Institutions Rating System (UFIRS) - is an abbreviation for the supervisory rating system U.S. regulators have developed to assess a bank's condition, based on its Capital adequacy, Asset quality, Management, Earnings, Liquidity, and Sensitivity to market risk. Ratings are not released to the public but general information on the system is available here: www.fdic.gov/regulations/laws/rules/5000-900.html.

${ }^{23}$ See the CRP website (www.opensecrets.org) for more details.
} 
finds common words) enabling us to generate a list of potential matches between the names in CRP and SNL Financial. We then manually check whether the pairs of name strings are actual matches with current and historical bank names via eyeballing, web searches, and additional information provided in disclosure filings. We also assign the lobbying activities from the parent institution, if any, to an individual bank because individual banks may benefit from the lobbying done by their parent without necessarily lobbying on their own. The main lobbying variables used in the analysis (see Table A.1 in the appendix for definitions) are constructed with the following information from lobbying disclosure filings: the name of the registrant (i.e., the lobbying firm) and the name of the client (in case of in-house lobbying the bank is the registrant and client); the annual amount the client pays, which is calculated by the CRP by summing the information in quarterly reports; and the name of agencies lobbied. First, we construct a variable that captures the bidder lobbying status during the current year of the bank failure date. More specifically, this is an indicator variable that takes the value of 1 if the bank lobbies the Treasury or any of the following relevant banking regulators: FDIC, Fed, OCC, and OTS. Second, we construct a variable that reflects the intensity with which a bank lobbies. This variable is the dollar amount of lobbying expenditures directed specifically toward the Treasury and the aforementioned banking regulators. Third, we create several other lobbying variables using additional information from the lobbying disclosure filings that are presented and discussed in Section III.C.

\section{Descriptive Statistics}

In Table 2 we present descriptive statistics of the main variables used in our analysis for failed banks (Panel A) and their bidders (Panel B). The vast majority of failed banks in our sample are state chartered (73 percent). ${ }^{24}$ At the time of the failure, the median failed bank's total assets are $\$ 203.5$ million, with a high standard deviation of $\$ 1.4$ billion. Bank failures impose substantial costs on the FDIC: the median cost of a sold failed bank in our sample is 23.5 percent of total assets of the failed bank, with a significant dispersion (standard deviation of 12.5 percent). ${ }^{25}$ Similar insights apply for the net discount, as defined by the difference between the asset discount and the deposit premium of the winning bid (standardized by total assets of the failed bank). In levels, the average cost of resolution amounts to $\$ 92.9$ million, with a median of $\$ 41.2$ million and a standard deviation of $\$ 153.1$ million. The resolution of bank failures in our sample led to DIF costs of approximately $\$ 45$ billion.

Comparing the characteristics of failed banks with bidding banks reveals interesting patterns. Bidding banks are, as expected, much larger than sold failed banks. The average bidding bank's assets are $\$ 8.8$ billion with a standard deviation of $\$ 3.3$ billion, while the average failed bank's assets amount to $\$ 605.3$ million (standard deviation of $\$ 1.4$ billion). Bidding banks are also well capitalized (average Tier 1 capital ratio of 15.8) and have no significant regulatory concerns (an

\footnotetext{
${ }^{24}$ From the 430 P\&A transactions in Table 1, 265 (untabulated) concerns state-chartered banks supervised by the Fed. State non-member banks and savings institutions (chartered and supervised by the FDIC) account for 63 of the transactions. Federally chartered banks (supervised by the OCC) are observed in 63 cases, while thrifts make up the remainder with 39 P\&A transactions at the time the OTS still existed.

${ }^{25}$ Bank failures typically represent a cost to the DIF because the FDIC, as the receiver of the failed institution, must liquidate assets that have declined substantially in value while, at the same time, making good on the institution's deposit obligations. The cost is calculated as the difference between the liabilities of the failed bank and the market value of its assets net of expenses incurred by the FDIC.
} 
average estimated CAMELS rating of 1.6). Bidding banks are located relatively close to failed banks with an average distance of 225 kilometers away from each other. Failed banks show on average a higher proportion of residential real estate loans (approximately 55 percent of their asset portfolio), though the bulk of lending from all banks in our sample tilts to real estate.

Many bidders are engaged in lobbying in 2007-2014 (18 percent of all bidders) as well as at the time of a target bank failure (12 percent). The proportion of lobbying banks in our sample is thus quite high given the high entry barriers to beginning to lobby (Bombardini, 2008; Kerr, Lincoln, and Mishra, 2014). The average lobbying expenditures (on any issues) in our sample are $\$ 86,720$, with a significant dispersion (standard deviation of $\$ 338,800$ ). Focusing on lobbying bidders only, they spent on average approximately $\$ 710,000$ (i.e., $42.56 \div 0.06$ in Panel B) on lobbying expenditures targeted at regulators during the year of the failure, again with a significant dispersion.

In Table 3 we compare characteristics of auction winners (i.e., acquirers) with auction losers. We note that acquirers tend to be located closer to failed banks relative to other bidders, consistent with Granja, Matvos, and Seru (2017). However, winners and losers do not appear to differ on many other characteristics but their lobbying activities. Acquiring banks tend to lobby significantly more than other bidders. The winner lobbying status is on average 5 percentage points higher than the one of losers. Acquirer's average lobbying expenditures targeted at banking regulators are almost doubling that of a loser $\left(e^{0.66}=1.93\right)$. Interestingly, winners also tend on average to satisfy less the FDIC qualifying criteria (see the five proxies we used in Table A.1) than losers. Figure 3 shows the lobbying activities by all bidding banks surrounding the bank failure date: auction winners (solid line) are consistently engaged in more lobbying activities than losers (dashed line). In Figure 4 we present the histogram of failed banks' total assets and further highlight the frequencies with which failed banks are acquired by banks engaged in lobbying. Moreover, we can observe that the distribution is skewed to the right (darker shaded bars), indicating that lobbying banks tend to acquire the largest failed banks. The solid line in Figure 4 shows this even more clearly by displaying the proportion of failed banks eventually acquired by a lobbying institution in a corresponding size range. In summary, these differences in means reported in Table 3 and the graphical illustrations in Figure 3 suggest that failed banks are likely to be sold to banks engaged in lobbying activities. We formalize these insights with the regression analysis to follow.

\section{EMPIRICAL Results ON FAILED-BANK AUCTIONS AND BIDDER LobBYING}

\section{A. Baseline Results}

To evaluate the effect of lobbying on the probability that a bidder wins a FDIC-run auction, we use $\Phi(\cdot)$ denoting a probit and estimate the specification

$$
\operatorname{Pr}\left(\operatorname{win}_{i j t}=1\right)=\Phi\left(\alpha+\beta l_{j t}+\Gamma_{j} X_{j t}+\Gamma_{i j} X_{i j t}+\mu_{i}+\mu_{t}+\varepsilon_{i j t}\right) \text {, }
$$

in which win $_{i j t}$ is a dummy variable equal to 1 if a bidder $j$ acquired failed bank $i$ at time $t$, and 0 if not. $\alpha$ is a constant term. $l_{j t}$ is a measure of bidder $j$ 's lobbying activities, usually either taking the value of 1 when the bidder directs its lobbying toward a banking regulator or calculated as the $\log$ of 1 plus the lobbying expenditures on banking regulators, measured in thousand dollars. $X_{j t}$ is a vector of control variables that always includes the following financial characteristics of bidder 
$j$ in the quarter prior to the failure date $t$ : Size, Liquidity Ratio, Tier 1 Capital Ratio, NPL Ratio, OREO Ratio, CRE Loans, C\&I Loans, and Residential Loans. $X_{i j t}$ is another vector of variables of proximity between a failed bank $i$ and a bidder $j$, which always includes the variable Distance, calculated as the log of the average distance of the branch network of the bidding bank $j$ from the branch network of the failed bank $i$, and Change in HHI, calculated as the average increase in local deposit market concentration across failed bank branch locations. ${ }^{26} \mu_{i}$ and $\mu_{t}$ represent a full set of failed bank and quarter fixed effects. The failed bank fixed effects $\mu_{i}$ ensure that our results are not driven by the characteristics of the bank being sold and its auction process, while quarter fixed effects $\mu_{t}$ control for any macro movements. The coefficient of interest is $\beta$, which measures the effect of lobbying on the probability that a bidder wins a FDIC-run auction. $\varepsilon_{i j t}$ is the error term. ${ }^{27}$ Throughout the main text, we report standard errors clustered at the level of the state where the failed bank's headquarters is located. In unreported results, we have bootstrapped standard errors obtained using 1,000 draws with replacement, and confirm that our results are robust.

Table 4 shows our basic regressions, estimates of equation (1). The results across columns 1-4 confirm the intuition from Figure 3 that lobbying is positively associated with the probability of acquiring a failed bank. Column 1 is the most parsimonious specification regressing the probability of winning an auction on our lobbying dummy variable and both quarter and state fixed effects, meaning that all auctions (even with only one bidder) are considered. The probit estimate of $\beta$ yields a marginal effect of 0.1858 (s.e.= 0.0648), statistically significant at the 1 -percent level. In column 2, we estimate the same specification as in column 1 but we replace state fixed effects by failed bank fixed effects $\mu_{i}$, which allow for within auction differences in lobbying status of bidders to the failed bank. The inclusion of $\mu_{i}$ implies that auctions with only one bidder are dropped. The average marginal effect estimate on lobbying status is 0.3425 (s.e. $=0.0648$ ), statistically significant at the 1-percent level.

Column 3 is our standard specification, which adds controls for financial characteristics of bidders, their distance to the failed bank, and change in market concentration. The result on lobbying is statistically and economically meaningful. The estimate, 0.2640 (s.e. $=0.0680$ ), implies that targeted lobbying on regulators increases the probability of winning the auction by 26.4 percentage points. Column 4 mirrors the specification in column 3 but turns to estimating the effect of lobbying expenditures. The coefficient estimate on lobbying expenditures is 0.0208 (s.e. $=0.0051$ ), again statistically significant at the 1-percent level. In economic terms, a one-standard-deviation increase in targeted lobbying expenditures on regulators (3.17) leads to an increase in the probability that a bidder wins the auction by 6.6 percentage points. ${ }^{28}$

\footnotetext{
${ }^{26}$ All our results presented in the next sections are robust to the inclusion of other variables in $X_{j t}$ (Core Deposits, State Bank, Estimated CAMELS Rating) and $X_{i j t}$ (Prospective Bidder, Distance $X$ Loans), respectively. We do not report them in the paper for brevity reasons.

${ }^{27}$ As a robustness check, we also run conditional fixed-effect logit regressions $\Phi\left(\cdots \mid \mu_{i}\right)$ in which bidder-failed bank pairs are grouped by the failed bank $i$ and the likelihood is calculated relative to each group $\left(\mu_{i}\right.$ denotes the fixed effect for failed bank $i$ ). The results obtained are very similar and, thus, not reported for brevity reasons.

${ }^{28}$ It is worthwhile emphasizing that we address self-selection bias in Table A.2 in the appendix by performing a Heckman-probit analysis. Bidders may indeed self-select to bid upon the invitation from the FDIC to join an auction, raising concerns that our results do not apply to a representative prospective bidder. Based on the qualifying criteria
} 
The evidence from control variables in columns 3 and 4 shows that winning bidders are relatively larger and less liquidity-constrained than losers. By contrast, the coefficient on capitalization (as measured by Tier 1 Capital Ratio) is not statistically distinguishable from zero, suggesting that actual bidders do not differ much in their ability to pay for the failed bank (see Granja, Matvos, and Seru, 2017). The coefficient estimate on geographical distance indicates that bidders that are located farther from a failed bank have a lower probability of acquiring it.

Overall, these results suggest that the odds for a bidder of winning a FDIC-run auction are positively associated with the bidder's lobbying status and expenditures. Next, we address potential endogeneity concerns by devising an instrumental variable (IV) strategy.

\section{B. Instrumental Variable Results}

One potential concern with the results above is that the variable of interest $l_{j t}$ is correlated with the error term $\varepsilon_{i j t}$, leading to inconsistent and biased estimates of $\beta$. Bidder-specific omitted factors might drive both lobbying activities and the auction process, affecting both $l_{j t}$ and $\operatorname{Pr}\left(\operatorname{win}_{i j t}=1\right)$. For example, lobbying activities of bidders could simply proxy for their ability and expertise in acquiring and integrating other institutions, increasing their probability of winning. Arguably, lobbying might also be the result of the bidder's expectation and willingness to win the auction, rather than its driver. These challenges are not unique to our data, but are likely concerns with any data where lobbying and auction outcomes are simultaneously observed.

We address these concerns in Table 5 by exploiting variation in bidder lobbying activities that is exogenous to the auction process of the failed bank. Kerr, Lincoln, and Mishra (2014) demonstrate that firms' lobbying decision engenders high upfront costs, which creates an option value associated with continuing to lobby over time..$^{29}$ Once firms get into the lobbying process, they tend to stay in because they would prefer not to incur these upfront (sunk) costs to set up a lobbying operation again in the near future. The propensity of a bank $j$ to lobby in general (i.e., on any issue area and regulatory bodies) highly conditions the lobbying done on failed bank acquisitions in a specific point in time. We exploit bidder lobbying activities (i.e., status or expenditures) not directed toward relevant banking regulators in the context of FDIC-run auctions to instrument for targeted lobbying activities at the relevant regulators. This instrument thus likely satisfies the exclusion restriction by construction. Furthermore, there are few reasons to believe that lobbying on regulators and political bodies that are unrelated to bankruptcy and finance would directly interfere with the decisions of banking regulators and, in particular, the FDIC.

\footnotetext{
reported in Table A.1, we extend the bidder sample to all prospective bidders for each failed-bank auction. We then employ the Heckman-probit method, for which both the dependent variable $\left(\right.$ win $\left._{i j t}\right)$ and participation variable $\left(\right.$ bid $\left._{i j t}\right)$ are binary. The specifications mirror the ones of Table 4, while the specifications on bidding probability further add bidder fixed effects. From the regression output in Table A.2, it can be seen that the estimations of lobbying on the probability of winning are qualitative similar than in Table 4. At the same time, we do not find that lobbying significantly affects banks' propensity to participate into an auction. The Wald tests also fail to reject the null, suggesting that our probit estimations reported in Table 4 are appropriate.

${ }^{29}$ These upfront costs are, for instance, searching for and hiring the right lobbyists and, once hired, educating them about the bank's interests and agenda, learning about the complexity of the political process and exploring how best to attempt to affect it, etc. This is discussed at length in Drutman (2015).
} 
We construct an instrument, derived from the above intuition, measuring lobbying on any political or regulatory bodies other than the Treasury, FDIC, Fed, OCC, OTS, for each bidder in our sample. The instrument is - depending on the instrumented variable used-either equal to 1 if the bidder $j$ lobbies on any non-banking regulators at time $t$ and 0 otherwise, or is the log of 1 plus the lobbying expenditures directed toward any non-banking regulators at time $t$, measured in thousand dollars. We also include the same set of control variables (Size, Liquidity Ratio, Tier 1 Capital Ratio, NPL Ratio, OREO Ratio, CRE Loans, C\&I Loans, Residential Loans, Distance, Change in HHI) and fixed effects $\left(\mu_{i}\right.$ and $\left.\mu_{t}\right)$ in the first stage and again cluster the standard errors at the level of the state of the failed bank's headquarters. Non-regulator lobbying is, as expected, positively associated with lobbying on banking regulators in both models of Table 5. The first-stage estimates are statistically significant at the 1-percent level.

The second-stage results show that our inferences from Table 4 remain the same. In Model (1) we estimate equation (1) while instrumenting our dummy variable of banking regulator lobbying with a dummy variable of non-banking regulator lobbying and the same control variables and fixed effects as before. The IV-probit estimate of the marginal effect of our lobbying dummy variable is in line with the probit estimate of Table 4, though it results in a slight fall in the coefficient to 0.2183 (s.e. $=0.0949$ ). ${ }^{30}$ Economically, this implies that targeted lobbying on regulators increases the probability of winning by 21.8 percentage points. In Model (2) we instrument instead lobbying expenditures on banking regulators using the corresponding instrument in dollar value. Again, the IV-probit estimate mirrors the baseline estimate from Table 4, and gives a smaller estimate of 0.0175 (s.e. $=0.0078$ ). Comparing this estimate with the corresponding probit estimate in Table 4 column 4 shows that it is about 15 percent smaller. The small sample size may also affect the validity of our inferences here. We accordingly adopt a bootstrap procedure (unreported), which is particularly useful in our case since our auction sample, though rather small, represents very closely the (distribution of the) population. Inferences drawn using bootstrapped standard errors show that IV coefficients on both lobbying variables are statistically stronger.

We also report at the bottom of Table 5 the Wald statistic and $p$-value for the test of the null hypothesis of no endogeneity; that is, testing whether the correlation parameter $\rho$ is equal to zero. We fail to reject the null in both models (test statistics are insignificant), suggesting that probit regressions from Table 4 are appropriate.

\section{Alternative Lobbying Measures}

In Table 6 we examine various alternative channels through which lobbying may generate an advantage to win an auction conducted by the FDIC in 2007-2014. Throughout the table, we use our standard specification of column 3 in Table 4, and sequentially add different lobbying measures.

First, lobbyists differ in terms of network that they can deploy to reach out regulators. An important characteristic in this respect is the lobbyist's past employment experience at any of the relevant banking regulators or membership at financial subcommittees of the Congress. In column 1 we investigate the relevance of this characteristic, best known as the "revolving-door" status of lobbyists. The coefficient estimate is 0.5850 (s.e. $=0.0767)$, statistically significant at the 1-percent

${ }^{30}$ The estimation result is qualitatively similar if a bivariate probit model is used. 
level. The economic effect is considerable: Revolving-door lobbyists increase the probability of winning by more than 50 percentage points. In column 2 we include instead a dummy variable equal to 1 if ( 0 if not) the bidder directs its lobbying toward banking regulators in combination with the help of a revolving-door lobbyists. Unsurprisingly, the effect is economically stronger $(\beta=0.7047$; s.e. $=0.1432)$ than in regression model estimated in column 1 , suggesting that lobbyists influence more easily the decisions of regulators for which they used to work.

Second, thus far we have investigated bidders' lobbying at the time of the failure without considering their past lobbying activities. In columns 3 and 4, we evaluate the impact of lobbying performed during the eight quarters prior to the failure date employing, similarly as before, a $0-1$ indicator and a dollar-value variable, respectively. The coefficient estimates are statistically significant at the 1-percent level, and of slightly larger magnitude than their counterparts in Table 4.

Third, since the FDIC has complete control over the receivership process, one could argue that the FDIC is the regulatory authority that really matters when it comes to influencing the auction outcome. In columns 5 and 6 , we respectively use a $0-1$ indicator and a dollar-value variable capturing the lobbying directed specifically toward the FDIC. The results reveal to be consistent in terms of order of magnitude and statistical significance. For instance, the estimate in column 5, 0.2477 (s.e. $=0.0618$ ), means that lobbying targeted at the FDIC increases the probability of winning a failed-bank auction by 24.8 percentage points. This indicates that an important part of the effect of lobbying shows up when the bidder establishes a lobbying contact directly with FDIC agents.

\section{Auction Competition}

A simple look at Table 1 reveals that competition between bidders varies across auctions, with auctions gathering as little as one bidder to auctions involving a dozen of bidders. Although our standard specification includes failed bank fixed effects which control for auction-specific factors such as competition, we conclude the analysis of this section by further examining whether the competitive process of an auction drives the probability of winning of lobbying bidders. Table 7 presents the results, and shows that the effect of lobbying continues to hold regardless of auction competition.

Specifically, in column 1 we split the sample between auctions according to the number of bidders involved; that is, two bidders and more than two bidders. Our independent variables of interest are the interaction terms between our lobbying dummy variable and a dummy variable taking the value of 1 if the number of bidders participating in the auction is two (or strictly above two). Both interactions terms enter positively and statistically significantly in the regression model (i.e. our standard specification). ${ }^{31}$ The coefficient estimate is larger for the interaction considering only two bidders: 0.6799 versus 0.1786 . In column 2 we split the sample differently. We analyze auctions including two bidders, three bidders, and four bidders, and strictly more than four bidders, respectively. Again, the results are consistent. Note, however, that the interaction term with the

\footnotetext{
${ }^{31}$ We follow Norton, Wang, and Ai (2004) to estimate the average marginal effects and standard errors. Because their recommended Stata command does not deal with multiple interactions, we use the more flexible MARGINS command (see also Berger and Bouwman, 2013).
} 
dummy variable of more than four bidders turns out to be statistically insignificant at conventional levels, possibly due to the resulting lack of statistical power. In columns 3 and 4, we replicate this strategy by interacting instead our dollar-value lobbying variable. The result obtained provides similar insights than in columns 1 and 2. All in all, our results here indicate that the effect of lobbying persists whatever the competition between bidders, with a more pronounced effect (though unsurprisingly) the lower the competition is.

\section{Assessing the (Mis)ALlocation OF FAILED BANKS DUE to LobBying}

\section{A. Acquirers' Bids and Resolution Costs}

As documented previously, selling failed banks leads to important costs for the FIDC that may greatly vary across bank resolutions. In this section, we explore whether selling failed banks to lobbying acquirers affects FDIC losses. A simple cut in the data reported in Figure 5 suggests that this is the case. It shows the distribution of resolution costs contrasted with the size of sold failed banks in our sample that we split according to the lobbying status of the acquirer. The median resolution cost of failed banks sold to acquirers engaged in lobbying amounts to $\$ 96.4$ million, which is much higher than for failed banks sold to non-lobbying acquirers (median of $\$ 36.4$ million).

Next, we compare the resolution cost resulting from an actual transaction to what the FDIC would have incurred if another bid would have been chosen, and gauge whether lobbying affects this differential. The submitted bids to the FDIC have two parts: (1) the discount the bidder requires for acquiring the failed bank's assets; and (2) the premium the bidder is prepared to pay for assuming the deposits. The difference between the two parts represents the net discount offered by the bidder on the failed bank's assets and liabilities. A higher (positive) net discount means a higher net payment from the FDIC to the acquirer. ${ }^{32}$ Here we study the relationship between bidder lobbying and the difference in net discount between the acquirer and the bidder whom the FDIC viewed as the second best (i.e., the cover bidder). Importantly, looking at the net discount differential also mitigates concerns about unobserved failed-bank characteristics potentially correlated with the resolution process. We perform OLS regressions of the following specification:

$$
\operatorname{cost}_{i t s}=\alpha+\beta l_{i t}+\Gamma X_{i t s}+\mu_{t}+\mu_{s}+\varepsilon_{i t s}
$$

in which $i$ denotes a sold failed bank, $t$ a quarter and $s$ a state. The dependent variable, cost $_{i t s}$, is the difference in net discount between the acquirer and the cover bidder, standardized by total assets of the failed bank. The net discount differential gives an indication of the incremental loss (gain) for the DIF that should have been realized if the FDIC Board had selected the cover bid. $l_{i t}$ is a measure capturing the lobbying (i.e., status and expenditures) of both the acquirer and the cover bidder. $X_{i t s}$ controls for failed bank's characteristics including the variables Size, Liquidity Ratio, Tier 1 Capital Ratio, NPL Ratio, OREO Ratio, CRE Loans, C\&I Loans, and Residential Loans. Moreover, $X_{i t s}$ contains bid characteristics of both acquirer and cover bidder, namely

\footnotetext{
${ }^{32}$ As an example, suppose that the acquirer views the failed bank's assets with a book value of $\$ 100$ as being worth $\$ 75$, but assumes responsibility for $\$ 100$ in deposits for which he is prepared to pay $\$ 10$, then the payment from the FDIC to the acquirer will be of $\$ 15$ (i.e., the net discount).
} 
dummy variables taking the value of 1 if ( 0 if not) the deal is for all loans and deposits of the failed bank, and other dummy variables taking the value of 1 if ( 0 if not) the transaction includes a losssharing agreement between the FDIC and the acquirer. $X_{i t s}$ also controls for the number of bids in each P\&A transaction. $\mu_{t}$ captures the quarter when the failed bank was sold, ensuring that the estimate is not driven by aggregate trends. We also include state fixed effects, $\mu_{s}$, to account for any differences between states (e.g., economic conditions, regulatory forbearance). We cluster standard errors at the level of the failed bank's state headquarters.

Columns 1 to 4 of Table 8 present the results of estimating equation (2). Across columns the coefficients on our lobbying variables suggest that acquirer lobbying increases the net discount differential, and thus the losses incurred by the FDIC. The magnitudes are large. In column 1, the independent variable of interest is the difference between the lobbying status (i.e., a 0-1 indicator) of the acquirer and the cover bidder. The coefficient estimate is 2.4037 (s.e.=1.0872) and statistically significant at the 5-percent level, indicating that when the acquirer has an advantage in terms of lobbying over the cover bidder it amplifies the loss for the DIF. In column 2, we estimate the effect of both acquirer and cover bidder lobbying separately, in lieu of their net effect. The coefficient estimate on acquirer lobbying status, 2.6498 (s.e.=1.2721), implies that the transfer to lobbying acquirers is estimated at $\$ 7.4$ billion for the DIF, or 16.4 percent of the total resolution losses of $\$ 44.99$ billion. ${ }^{33}$ Importantly, the coefficient estimate on cover bidder lobbying status is negative and insignificant. Columns 3 and 4 display consistent results when we consider the dollarvalue variables of lobbying. In terms of money spent on lobbying toward regulators (using coefficient estimates of column 4), a one-standard-deviation increase in lobbying expenditures (3.17) leads to an increase in the transfer from the DIF to lobbying acquirers of $\$ 1.7$ billion, which is equal to 3.8 percent of the total resolution losses.

Next we analyze cases for which the net discount submitted by the cover bidder on the failed bank's assets and liabilities is lower than the one eventually offered by the winning bidder. In such cases the FDIC accepts higher resolution costs by allocating the bank to the winner. We construct a dummy variable that takes the value of 1 if the acquisition price is lower than the cover price in terms of net discount, and 0 otherwise. We again control for bid characteristics such as the cover of some assets by loss-sharing agreements. The results presented in columns 5 to 8 show that the coefficient estimates on acquirer lobbying variables are always positive and statistically significant at the 1-percent level. Lobbying thus increases the likelihood that the FDIC selects a winning bid with a higher net discount.

To sum up, the results in this section are as follows: (1) lobbying increases the net discount differential, suggesting that lobbying acquirers pay on average relatively less than other-auction bidders; and (2) lobbying significantly increases the likelihood of winning with a greater net discount than the cover bidder, suggesting that lobbying acquirers tend to pay less than the cover bidder. Lobbying thus results in a significant drain for the FDIC insurance fund. Importantly, these findings also show that the FDIC makes more use of its discretion when bidders lobby. We now

\footnotetext{
${ }^{33}$ Using estimate of $\beta$ from column 2, 2.6498 percentage points of $\$ 278,306$ million of aggregated assets yield approximately $\$ 7,374.6$ million (= 16.4 percent of the aggregated resolution cost in Table 1 ).
} 
move on to studying outcomes following the investment in a failed bank to further establish whether the documented effect of lobbying can be interpreted as a sign of misallocation.

\section{B. Post-Acquisition Efficiency}

In this section, we formally examine whether the acquisition of failed banks by lobbying institutions leads to observable efficiency improvements. For that purpose, we construct a panel data set at the joint-bank (acquirer and failed bank combined) and quarter levels spanning the 2003-2015 interval and perform fixed-effects regressions of the specification

efficiency $_{j^{\prime} t}=\alpha+\beta_{1}$ post acquisition a $^{\prime} t+\beta_{2}\left(l_{j^{\prime}} \times\right.$ post acquisition $\left._{j^{\prime} t}\right)+\Gamma X_{j^{\prime} t}+\mu_{j^{\prime}}+$ $\mu_{t}+\varepsilon_{j^{\prime} t}$.

Here efficiency ${ }_{j^{\prime} t}$ is a measure of efficiency of the joint-bank $j^{\prime}$ at time $t$. Specifically, we employ return on assets (ROA) and the cost-to-asset ratio (Cost Ratio) as two complementary measures of efficiency that have been used in prior works (e.g. Cornett and Tehranian, 1992; and Granja, Matvos, and Seru, 2017, in a context similar than ours). The dummy variable post acquisition $_{j^{\prime} t}$ takes the value of 1 on the quarter after the failure and the subsequent quarters, and 0 otherwise. ${ }^{34}$ The interaction between $l_{j^{\prime}}$ and post acquisition $j^{\prime} t$ captures how bidder lobbying (i.e., status and expenditures) modifies the average effect of a failed bank's acquisition on the outcome variable efficiency ${ }_{j^{\prime} t}$. To isolate the effect of $\beta_{2}$, the coefficient of interest, we control for a host of joint-bank characteristics $\left(X_{j^{\prime}}\right)$ including Size, Liquidity Ratio, Tier 1 Capital Ratio, NPL Ratio, OREO Ratio, CRE Loans, C\&I Loans, and Residential Loans. We further add joint-bank and quarter fixed effects, $\mu_{j^{\prime}}$ and $\mu_{t}$, to remove the effect of fixed jointbank characteristics potentially correlated with lobbying or the acquisition itself on efficiency outcomes and to eliminate any common trends in both lobbying and acquisition potentially correlated with efficiency outcomes. The inclusion of $\mu_{j^{\prime}}$ in our specification thus absorbs the lobbying variable itself and only the interaction effect between the acquisition dummy and lobbying variable is identified. Standard errors are robust to heteroscedasticity and clustered at the joint-bank level.

Table 9 reports the results of assessing whether efficiency changes around the acquisition vary according to the lobbying activities of the eventual acquirer of failed banks. We measure the combined efficiency of an acquirer and the failed bank before the acquisition by weighting their individual efficiency measures, and then compare them after the transaction. Columns 1-4 first show that there are in general efficiency improvements after failed bank acquisitions: the postacquisition dummy variable enters positively and significantly in regression models of columns 1 and 2, which suggests that acquiring failed banks enhances operating performance as measured by ROA. Similarly, in columns 3 and 4 total expenses relative to total assets (Cost Ratio) decrease on average after the acquisition of a failed bank. The coefficient on the post-acquisition dummy variable, though insignificant, is negative.

\footnotetext{
${ }^{34}$ Because the time needed to finalize the integration of the failed bank may vary from one acquirer to the other, we drop observations during the four quarters starting from the failure date.
} 
When acquisitions involve a lobbying bank, they are associated with a relatively lower ROA and a higher Cost Ratio, suggesting efficiency deterioration compared to an average acquirer. First, the coefficient estimate of the interaction term in column 1 is -0.1771 (s.e. $=0.0272$ ), statistically significant at the 1-percent level. This means that ROA at lobbying banks decreases by about 18 basis points relative to a sample mean of 0.15 percent. The results are also economically meaningfully when we study the lobbying expenditures in column 2: a one-standard-deviation change in lobbying expenditures is associated with a drop in ROA by around 30 percent relative to the mean. Second, we focus on our cost measure (Cost Ratio) and find results in line with the ones on ROA. As can be observed from the remaining two columns of Table 9, we find that the takeovers of a failed institution by lobbying banks lead to significant increases in Cost Ratio, which corroborates the fact that post-takeover efficiency appears to deteriorate at lobbying banks.

Finally, we examine the market reaction of the lobbying acquirers around failed-bank acquisition announcement. For this purpose, we restrict our sample to bidders that are publicly listed, or have a parent bank holding company that is listed. ${ }^{35}$ As a prequel to this analysis, we begin by comparing the market reaction of the bidders - that is, both the winners and the losers - around the P\&A announcement date. Figure 6 plots the average abnormal returns (based on the market model) of bidders. It clearly shows that winning bidders (solid line) experience positive abnormal returns, while losing bidders (dashed line) have negative abnormal returns. Table 10 displays the CAR results and consistently shows in Panel A that the average three-day CAR for winners is 2.1 percent, which is 2.4 percentage points higher than for losers, who have an average CAR of -0.4 percent. ${ }^{36}$

We then gauge the potential differential effect of lobbying on winner CAR in Panel B, which presents the estimation results for the CAR regression analysis. Specifically, we regress the acquirer's three-day CAR $(-1,+1)$ surrounding the P\&A announcement date on one of our lobbying measures and a vector of control variables, including quarter and failed-bank state fixed effects. Column 1 shows that the average baseline effect of the winner's lobbying status is -2.7 percentage points, statistically significant at the 5-percent level. Column 2 augments the specification of column 1 with both acquirer-bank and failed-bank characteristics and shows once again that the winner's lobbying status negatively impacts on CAR: it diminishes by -0.9 percentage points relative to the sample mean acquirer CAR of 2.1 percent. The remaining columns of Panel B paint a consistent picture for winners' lobbying expenditures on their market value.

\section{Are Lobbying Bidders Engaged in Rent Seeking? A Discussion}

Our empirical analysis reveals that lobbying by bidders affects the outcomes of FDIC actions along two dimensions: lobbying bidders are more likely to win auctions and they pay relatively less to win. The implied negative relationship between price paid and likelihood of winning seems puzzling as it is at odds with standard economic theory. We have also shown that the both operating

\footnotetext{
${ }^{35}$ We thank the Federal Reserve Bank of New York for providing the linking file for CRSP and commercial banks (www.newyorkfed.org/research/banking_research/datasets.html).

36 This positive market reaction in failed-bank acquisitions is in line with evidence from the S\&L crisis (e.g., James and Wier, 1987). However, it contrasts strikingly with evidence from ordinary bank acquisitions, which generally do not elicit positive acquirer returns (e.g., DeLong and DeYoung, 2007; Minnick, Unal, and Yang, 2011).
} 
and stock market performance of lobbying banks post-acquisition falls relative to the total sample of acquiring banks. This is also surprising to the extent that lobbying banks may hence ultimately not benefit from their ability to acquire more easily. In this section, we discuss what could plausibly explain our findings.

One channel through which lobbying may affect acquisitions is rent seeking (Shleifer and Vishny, 1994); that is, lobbying allows bidders of receiving a more favorable treatment by the FDIC. ${ }^{37}$ This view can account for our finding that lobbying increases the likelihood of winning while simultaneously reducing the acquisition price for bidders. Rent seeking has the likely consequence that it distorts the efficient allocation of failed banks, as the regulatory agency is no longer solely guided by economic principles in its decisions. For example, while a failed bank should be allocated to the bidder that is best able to acquire and integrate the failing bank (and hence can offer the highest valuation), lobbying may lead to other banks being favored in the auction process. Our results on the post-acquisition efficiency are consistent with this: lobbying banks do not seem to be matched with failing banks in situations in which they are able to improve the performance.

An alternative channel depicts the lobbying process as one of information transmission (Grossman and Helpman, 2001). The informational view posits that lobbying resolves the information asymmetry inherent to the resolution process. The bidder's ability to acquire and integrate a failed institution might be private to the bidder, but lobbyists have the ability to convey it to the regulator. By gaining access to new information, the FDIC can in principle make superior decisions, selecting better matches for failing banks. This channel may thus account for our main finding that lobbying banks have a higher likelihood of winning the auction: everything else being equal, the FDIC should prefer bidders for which informational asymmetries are less pronounced. The informationbased explanation is also consistent with the fact that lobbying bidders are able to pay less, as the resolution of informational problems should increase the FDIC's willingness to allocate failed banks to lobbying banks. However, our last empirical finding, the lower operating and stock market performance of lobbying acquirers, does not fit with the case of better information dissemination since we would expect lobbying banks to only be allocated failed banks when they are good acquirers.

Our analysis further informs us about the reason for why banks may lobby. Two explanations can be brought forward. One is that lobbying is an efficient investment in regulatory capital. Banks make these investments in order to benefit from favorable treatment, allowing them to improve their overall return to shareholders (Acemoglu et al., 2016; Borisov, Goldman, and Gupta, 2016). Our auction results can be explained by this, as lobbying acquirers benefit from a lower price they have to pay. The results on the lower efficiency of acquiring firms, however, seem to be at odds with this explanation as acquiring firms will not benefit from a higher likelihood of winning auctions if this leads to inferior performance going forward.

The second explanation is that lobbying is the result of agency problems within the firm. Aggarwal, Meschke, and Wang (2012) highlight the common agency issues prevalent in rent-seeking situations characterizing corporate political contributions in the United States. The authors find that firms with high political contributions experience lower long-term stock returns, and have

\footnotetext{
${ }^{37}$ See Khwaja and Mian (2011) who discuss and review recent advances in the study of rent seeking in the financial sector.
} 
operating characteristics consistent with the existence of a free cash flow problem. In particular, firms that make political contributions tend to engage in more and worse acquisitions than firms that do not. In the context of the financial crisis, like ours, Duchin and Sosyura (2012) show that politically connected institutions are more likely to access to government investment funds. They also find that these investments in politically connected institutions underperform those in unconnected institutions, consistent with Shleifer-Vishny predictions on agency-type inefficiencies from political connections.

In our specific context, agency problems may take the form of empire-building managers, who realize that lobbying allows them to expand more easily through acquisitions. This is consistent with our finding that lobbying simultaneously raises the likelihood of being able to acquire another bank while at the same time lowering the performance of acquisitions. In this view, lobbying has a double cost: it distorts the efficient allocation of failed banks (a social cost) and amplifies agency problems at acquiring banks (a firm-level cost).

\section{Conclusion}

In this paper, focus has been on the political economy of the resolution of failed banks during the financial crisis and its aftermath. Studying the universe of P\&A transactions between 2007 and 2014, we find strong evidence that bidders engaged in lobbying activities are in better position to win a failed-bank auction. Further evidence suggests that rent seeking for favorable treatment is more likely to account for this finding. In particular, we show that eventual acquirers with lobbying activities deliver inferior outcomes in terms of post-acquisition efficiency, consistent with rentseeking theories à la Shleifer and Vishny (1994). We also assess the economic magnitude of the cost associated with the lobbying on failed-bank auctions and find that the cost imposed to the DIF is meaningful: the average effect estimated is equal to 16.4 percent of the total resolution losses. Of course, having shown that lobbying creates distortions at the bank level does not imply any welfare losses, as a swift and smooth acquisition (by lobbying banks) may benefit financial stability and lower the chances of economic disruptions. Understanding and quantifying further the welfare consequences of lobbying remains a fruitful area of future research. 


\section{References}

Acemoglu, Daron, Simon Johnson, Amir Kermani, James Kwak, and Todd Mitton, 2016. The value of connections in turbulent times: Evidence from the United States, Journal of Financial Economics 121, 368-399.

Acharya, Viral and Tanju Yorulmazer, 2007. Too many to fail-An analysis of time-inconsistency in bank closure policies, Journal of Financial Intermediation 24, 1-31.

Acharya, Viral and Tanju Yorulmazer, 2008. Cash-in-the-market pricing and optimal resolution of bank failures, Review of Financial Studies 21, 2705-2742.

Admati, Anat and Martin Hellwig, 2013. The Bankers' New Clothes: What's Wrong with Banking and What to Do About It (Princeton University Press, Princeton).

Aggarwal, Rajesh, Felix Meschke, and Tracy Wang, 2012. Corporate political contributions: Investment or agency? Business and Politics 14, 1-38.

Berger, Allen and Christa Bouwman, 2013. How does capital affect bank performance during financial crises? Journal of Financial Economics 109, 146-176.

Bertrand, Marianne, Matilde Bombardini, and Francesco Trebbi, 2014. Is it whom you know or what you know? An empirical assessment of the lobbying process, American Economic Review 104, 3885-3920.

Blanes i Vidal, Jordi, Mirko Draca, and Christian Fons-Rosen, 2012. Revolving door lobbyists, American Economic Review 102, 3731-3748.

Bombardini, Matilde, 2008. Firm heterogeneity and lobby participation, Journal of International Economics 75, 329-348.

Borisov, Alexander, Eitan Goldman, and Nandini Gupta, 2016. The corporate value of (corrupt) lobbying, Review of Financial Studies 29, 1039-1071.

Bovenzi, John F., 2015. Inside the FDIC: Thirty Years of Bank Failures, Bailouts, and Regulatory Battles (John Wiley \& Sons, New Jersey).

Brown, Craig and Serdar Dinc, 2005. The politics of bank failures: Evidence from emerging markets, Quarterly Journal of Economics 120, 1413-1444.

Claessens, Stijn and Laura Kodres, 2014. The regulatory responses to the global financial crisis: Some uncomfortable questions, IMF Working Paper No. 14/46.

Cole, Rebel and Lawrence White, 2017. When time is not on our side: The costs of regulatory forbearance in the closure of insolvent banks, Journal of Banking and Finance, forthcoming.

Cornett, Marcia and Hassan Tehranian, 1992. Changes in corporate performance associated with bank acquisitions, Journal of Financial Economics 31, 211-234.

DeLong, Gayle and Robert DeYoung, 2007. Learning by observing: Information spillovers in the execution and valuation of commercial bank M\&As, Journal of Finance 62, 181-216.

Drutman, Lee, 2015. The Business of America is Lobbying. How Corporations Became Politicized and Politics Became More Corporate (Oxford University Press, Oxford).

Duchin, Ran and Denis Sosyura, 2012. The politics of government investment, Journal of Financial Economics 106, 24-48. 
Eckbo, Espen and Karin Thorburn, 2008. Automatic bankruptcy auctions and fire-sales, Journal of Financial Economics 89, 404-422.

Facchini, Giovanni, Anna Maria Mayda, and Prachi Mishra, 2011. Do interest groups affect US immigration policy? Journal of International Economics 85, 114-128.

Federal Deposit Insurance Corporation (FDIC), 2003. Managing the Crisis: The FDIC and RTC Experience (FDIC, Washington, DC).

Federal Deposit Insurance Corporation (FDIC), 2014. Resolutions Handbook (FDIC, Washington, $\mathrm{DC})$.

Giliberto, Michael and Nikhil Varaiya, 1989. The winner's curse and bidder competition in acquisitions: Evidence from failed bank auctions, Journal of Finance 44, 59-75.

Granja, Joao, 2013. The relation between bank resolutions and information environment: Evidence from the auctions for failed banks, Journal of Accounting Research 51, 1031-1070.

Granja, Joao, Gregor Matvos, and Amit Seru, 2017. Selling failed banks, Journal of Finance 72, $1723-1784$.

Grossman, Gene and Elhanan Helpman, 2001. Special Interest Politics (MIT Press, Cambridge).

Hynes, Richard and Steven Walt, 2010. Why banks are not allowed in bankruptcy, Washington \& Lee Law Review 67, 985-1051.

Igan, Deniz and Prachi Mishra, 2014. Wall Street, Capitol Hill, and K Street: Political influence and financial regulation, Journal of Law and Economics 57, 1063-1084.

Igan, Deniz, Prachi Mishra, and Thierry Tressel, 2012. A Fistful of dollars: Lobbying and the financial crisis, NBER Macroeconomics Annual 26, 195-230.

Imai, Masami, 2009. Political influence and declarations of bank insolvency in Japan, Journal of Money, Credit and Banking 41, 131-158.

International Monetary Fund (IMF), 2015. United States: Financial sector assessment program review of the key attributes of effective resolution regimes for the banking and insurance sectors - technical note, IMF Country Report No. 15/171.

International Monetary Fund (IMF) and the World Bank (WB), 2009. An Overview of the Legal, Institutional, and Regulatory Framework for Bank Insolvency, April 17; available at https://www.imf.org/external/np/pp/eng/2009/041709.pdf.

James, Christopher, 1991. The losses realized in bank failures, Journal of Finance 46, 1223-1242.

James, Christopher and Peggy Wier, 1987. An analysis of FDIC failed bank auctions, Journal of Monetary Economics 20, 141-153.

Kane, Edward, 1989. The S\&L Insurance Mess: How Did it Happen? (Urban Institute Press, Washington, DC).

Kerr, William, William Lincoln, and Prachi Mishra, 2014. The dynamics of firm lobbying, American Economic Journal: Economic Policy 6, 343-379.

Khwaja, Asim Ijaz and Atif Mian, 2011. Rent seeking and corruption in financial markets, Annual Review of Economics 3, 579-600. 
Kisin, Roni and Asaf Manela, 2016. Funding and incentives of regulators: Evidence from banking, Working Paper, Washington University in St. Louis.

Kroszner, Randall and Philip Strahan, 1996. Regulatory incentives and the thrift crisis: Dividends, mutual-to-stock conversions, and financial distress, Journal of Finance 51, 1285-1319.

Laffont, Jean-Jacques and Jean Tirole, 1993. A Theory of Incentives in Procurement and Regulation (MIT Press, Cambridge).

Lambert, Thomas, 2017. Lobbying on regulatory enforcement actions: Evidence from U.S. commercial and savings banks, Management Science, forthcoming.

Lambert, Thomas and Paolo Volpin, 2017. Endogenous political institutions and financial development, in Thorsten Beck and Ross Levine, eds.: Handbook of Finance and Development (Edward Elgar, London), forthcoming.

Liu, Wai-Man and Phong Ngo, 2014. Elections, political competition and bank failure, Journal of Financial Economics 112, 251-268.

McCarty, Nolan, Keith Poole, and Howard Rosenthal, 2013. Political Bubbles. Financial Crises and the Failure of American Democracy (Princeton University Press, Princeton).

Mian, Atif, Amir Sufi, and Francesco Trebbi, 2010. The political economy of the US mortgage default crisis, American Economic Review 100, 1967-1998.

Mian, Atif, Amir Sufi, and Francesco Trebbi, 2013. The political economy of the subprime mortgage credit expansion, Quarterly Journal of Political Science 8, 373-408.

Minnick, Kristina, Haluk Unal, and Liu Yang, 2011. Pay for performance? CEO compensation and acquirer returns in BHCs, Review of Financial Studies 24, 439-472.

Morrison, Edward, 2010. Bankruptcy and restructuring of financial institutions (discussion remarks), New York University Journal of Law and Business 6, 241-280.

Norton, Edward, Hua Wang, and Chunrong Ai, 2004. Computing interaction effects and standard errors in logit and probit models, Stata Journal 4, 154-167.

Philippon, Thomas and Aude Salord, 2017. Bail-ins and bank resolution in Europe: A progress report, Geneva Special Report on the World Economy 4, ICMB and CEPR.

Shleifer, Andrei and Robert Vishny, 1994. Politicians and firms, Quarterly Journal of Economics $109,995-1025$.

Stromberg, Per, 2000. Conflicts of interest and market illiquidity in bankruptcy auctions: theory and tests, Journal of Finance 55, 2641-2692.

Thorburn, Karin, 2000. Bankruptcy auctions: costs, debt recovery, and firm survival, Journal of Financial Economics 58, 337-368.

Veronesi, Pietro and Luigi Zingales, 2010. Paulson's gift, Journal of Financial Economics 97, 339-368.

Walther, Ansgar and Lucy White, 2016. Rules versus discretion in bank resolution, Working Paper, Harvard University. 


\section{Appendix}

Table A.1. Variable Definitions

\begin{tabular}{ll}
\hline Variable & Definition \\
\hline Auction Outcomes: & $\begin{array}{l}\text { Indicator that takes the value of } 1 \text { if the bank wins the auction of a } \\
\text { failed bank and } 0 \text { otherwise. }\end{array}$ \\
Indicator that takes the value of 1 if the bank submits a bid in the \\
auction of a failed bank and 0 otherwise. \\
The cost borne by the FDIC in the resolution process of each failed \\
bank as a percentage of the total assets of the failed bank at the time \\
of failure. \\
Thesolution Cost \\
of total assets of the failed bank subtracted by deposit premium, \\
standardized by total assets of the failed bank.
\end{tabular}


Table A.1. continued

\begin{tabular}{|c|c|}
\hline Variable & Definition \\
\hline \multicolumn{2}{|c|}{ Bank Characteristics (continued): } \\
\hline $\operatorname{CAR}(-1,+1)$ & $\begin{array}{l}\text { Cumulative three-day abnormal return of acquirer's bank holding company at } \\
\text { the date of the FDIC press release announcing the acquisition, based on } \\
\text { market model. The estimation window is the }(-254,-42) \text { trading-day window } \\
\text { before the failure date. We drop bidders that have less than } 100 \text { valid } \\
\text { observations in the estimation window. }\end{array}$ \\
\hline Size & Log of total assets (in thousand dollars) (RCFD2170). \\
\hline Liquidity Ratio & $\begin{array}{l}\text { Liquid assets (Cash (RCFD0010) + Fed Funds Sold (RCONB987+ } \\
\text { RCFDB989 + Securities excluding MBS/ABS) (RCFD1754 + RCFD1773 - } \\
\text { (RCFD8500 + RCFD8504 + RCFDC026 + RCFD8503 + RCFD8507 + } \\
\text { RCFDC027) divided by total assets. }\end{array}$ \\
\hline Tier 1 Capital Ratio & Tier 1 core capital divided by total risk-weighted assets. \\
\hline NPL Ratio & $\begin{array}{l}\text { Non-performing loans (non-accrual) and } 90 \text { days or more past due } \\
\text { (RCFD1407 + RCFD1403) divided by total loans. }\end{array}$ \\
\hline OREO Ratio & Other real estate owned (RCFD2150) divided by total assets. \\
\hline CRE Loans & $\begin{array}{l}\text { Percentage of Commercial and Real Estate (CRE) loans (RCFD2746) relative } \\
\text { to total loans. }\end{array}$ \\
\hline C\&I Loans & $\begin{array}{l}\text { Percentage of Commercial and Industrial (C\&I) loans (RCFD1600) relative } \\
\text { to total loans. }\end{array}$ \\
\hline Residential Loans & $\begin{array}{l}\text { Percentage of residential real estate loans (RCFD1797 + RCFD1798) relative } \\
\text { to total loans (RCFD1400). }\end{array}$ \\
\hline Core Deposits & $\begin{array}{l}\text { Total core deposits (transaction accounts }+ \text { savings deposits }+ \text { time deposits } \\
\text { less than } \$ 100,000 \text { ) divided by total deposits. }\end{array}$ \\
\hline State Bank & $\begin{array}{l}\text { Indicator that takes the value of } 1 \text { if the bank is regulated by a state regulator } \\
\text { and } 0 \text { otherwise. }\end{array}$ \\
\hline Estimated CAMELS Rating & Estimated CAMELS rating provided by SNL Financial. \\
\hline \multicolumn{2}{|l|}{ Proximity to Failed Banks: } \\
\hline \multirow[t]{5}{*}{ Prospective Bidder } & $\begin{array}{l}\text { Indicator that takes the value of } 1 \text { if a bank is a qualified bidder for a failed } \\
\text { bank. A qualified bidder satisfies the following conditions: }\end{array}$ \\
\hline & $\begin{array}{l}\text { 1. The bank is a commercial bank or a savings bank operating in the United } \\
\text { States; }\end{array}$ \\
\hline & $\begin{array}{l}\text { 2. Tier } 1 \text { Capital Ratio is below } 10 \% \text { in the quarter prior to the failure date; } \\
\text { 3. Estimated CAMELS Rating is not higher than } 2 \text { in the quarter prior to the } \\
\text { failure date; }\end{array}$ \\
\hline & $\begin{array}{l}\text { 4. Size is at least twice that of the failed bank if the headquarter of the bank } \\
\text { is in the same state of the failed bank headquarter, four times if in an } \\
\text { adjacent state, and five times if in a non-adjacent state; }\end{array}$ \\
\hline & 5. The bank is not a merger target in the quarter of the failure date. \\
\hline Distance & $\begin{array}{l}\text { Log of average pairwise distance in kilometers between all pairs of branches } \\
\text { of the failed bank and the bidding bank. }\end{array}$ \\
\hline Distance $X$ Loans & $\begin{array}{l}\text { Absolute difference in } X \text { Loans between the bidder and the failed bank, with } \\
X \text { meaning CRE, C\&I, or Residential Loans. }\end{array}$ \\
\hline Change in HHI & $\begin{array}{l}\text { The increase in local deposit market concentration that would result from a } \\
\text { bidding bank acquiring the failed bank, averaged across the branch network } \\
\text { of the failed bank. }\end{array}$ \\
\hline
\end{tabular}


Table A.2. Auction Winning Likelihood, Endogenous Bidding, and Bidder Lobbying: HeckmanProbit Results

This table reports the results of Heckman-probit regressions. $\operatorname{Pr}($ Win) and $\operatorname{Pr}(\mathrm{Bid})$ columns report coefficient estimates and Marginal Effects columns report the average marginal effects on the likelihood of winning an auction. Control variables include financial characteristics of bidders in the quarter prior to failure dates-Size, Liquidity Ratio, Tier 1 Capital Ratio, NPL Ratio, OREO Ratio, CRE Loans (\%), C\&I Loans (\%), and Residential Loans (\%) — and proximity measures-Distance and Change in HHI. See Table A.1 for more details about variable definitions. All variables are winsorized at the $1^{\text {st }}$ and $99^{\text {th }}$ levels. Robust standard errors of marginal effects are presented in the parentheses and clustered at the level of the failed bank's state headquarters. $* * *, * *$, and * represent statistical significance at $1 \%$, $5 \%$, and $10 \%$ levels.

\begin{tabular}{|c|c|c|c|c|c|c|}
\hline & \multicolumn{3}{|c|}{$(1)$} & \multicolumn{3}{|c|}{$(2)$} \\
\hline & $\operatorname{Pr}($ Win $)$ & $\begin{array}{c}\text { Marginal } \\
\text { Effects }\end{array}$ & $\operatorname{Pr}(\mathrm{Bid})$ & $\operatorname{Pr}($ Win $)$ & $\begin{array}{c}\text { Marginal } \\
\text { Effects }\end{array}$ & $\operatorname{Pr}(\mathrm{Bid})$ \\
\hline Lobbying Regulator $>0$ & $\begin{array}{c}0.7158^{* * * *} \\
(0.2157)\end{array}$ & $\begin{array}{l}0.1124 * * \\
(0.0489)\end{array}$ & $\begin{array}{c}0.1578 \\
(0.6207)\end{array}$ & & & \\
\hline Lobbying Regulator & & & & $\begin{array}{c}0.0536^{* * *} \\
(0.0162) \\
\end{array}$ & $\begin{array}{c}0.0084 * * \\
(0.0035) \\
\end{array}$ & $\begin{array}{c}0.0019 \\
(0.0611) \\
\end{array}$ \\
\hline Size & $\begin{array}{c}0.0639 \\
(0.1123)\end{array}$ & $\begin{array}{c}0.0100 \\
(0.0205)\end{array}$ & $\begin{array}{c}-1.4541 * * * \\
(0.1931)\end{array}$ & $\begin{array}{c}0.0641 \\
(0.1126)\end{array}$ & $\begin{array}{c}0.0101 \\
(0.0207)\end{array}$ & $\begin{array}{c}-1.4552 * * * \\
(0.1920)\end{array}$ \\
\hline Liquidity Ratio & $\begin{array}{l}0.0151 * * \\
(0.0072)\end{array}$ & $\begin{array}{c}0.0024 \\
(0.0017)\end{array}$ & $\begin{array}{l}-0.0133^{*} \\
(0.0073)\end{array}$ & $\begin{array}{l}0.0150 * * \\
(0.0073)\end{array}$ & $\begin{array}{c}0.0024 \\
(0.0017)\end{array}$ & $\begin{array}{c}-0.0133^{*} \\
(0.0073)\end{array}$ \\
\hline Tier 1 Capital Ratio & $\begin{array}{c}0.0218 \\
(0.0150)\end{array}$ & $\begin{array}{c}0.0034 \\
(0.0025)\end{array}$ & $\begin{array}{l}0.0199 * \\
(0.0114)\end{array}$ & $\begin{array}{c}0.0219 \\
(0.0151)\end{array}$ & $\begin{array}{c}0.0034 \\
(0.0025)\end{array}$ & $\begin{array}{l}0.0198^{*} \\
(0.0115)\end{array}$ \\
\hline NPL Ratio & $\begin{array}{l}-0.0287 \\
(0.0273)\end{array}$ & $\begin{array}{l}-0.0045 \\
(0.0053)\end{array}$ & $\begin{array}{l}-0.0194 \\
(0.0135)\end{array}$ & $\begin{array}{l}-0.0284 \\
(0.0274)\end{array}$ & $\begin{array}{l}-0.0045 \\
(0.0053)\end{array}$ & $\begin{array}{l}-0.0195 \\
(0.0136)\end{array}$ \\
\hline OREO Ratio & $\begin{array}{l}-0.0370 \\
(0.1734)\end{array}$ & $\begin{array}{l}-0.0058 \\
(0.0280)\end{array}$ & $\begin{array}{c}0.1023 \\
(0.0622)\end{array}$ & $\begin{array}{l}-0.0379 \\
(0.1729)\end{array}$ & $\begin{array}{l}-0.0060 \\
(0.0280)\end{array}$ & $\begin{array}{c}0.1020 \\
(0.0625)\end{array}$ \\
\hline CRE Loans (\%) & $\begin{array}{c}0.0086 \\
(0.0099)\end{array}$ & $\begin{array}{c}0.0014 \\
(0.0016)\end{array}$ & $\begin{array}{l}-0.0289 * \\
(0.0165)\end{array}$ & $\begin{array}{c}0.0087 \\
(0.0099)\end{array}$ & $\begin{array}{c}0.0014 \\
(0.0016)\end{array}$ & $\begin{array}{l}-0.0288 * \\
(0.0164)\end{array}$ \\
\hline C\&I Loans (\%) & $\begin{array}{l}-0.0044 \\
(0.0083)\end{array}$ & $\begin{array}{l}-0.0007 \\
(0.0013)\end{array}$ & $\begin{array}{l}-0.0250 \\
(0.0154)\end{array}$ & $\begin{array}{l}-0.0045 \\
(0.0083)\end{array}$ & $\begin{array}{l}-0.0007 \\
(0.0013)\end{array}$ & $\begin{array}{l}-0.0248 \\
(0.0153)\end{array}$ \\
\hline Residential Loans (\%) & $\begin{array}{c}0.0015 \\
(0.0078)\end{array}$ & $\begin{array}{c}0.0002 \\
(0.0013)\end{array}$ & $\begin{array}{c}-0.0279 * * \\
(0.0118)\end{array}$ & $\begin{array}{c}0.0015 \\
(0.0078)\end{array}$ & $\begin{array}{c}0.0002 \\
(0.0013)\end{array}$ & $\begin{array}{c}-0.0279 * * \\
(0.0118)\end{array}$ \\
\hline Distance & $\begin{array}{c}-0.2560 * * * \\
(0.0908)\end{array}$ & $\begin{array}{c}-0.0402 * * * \\
(0.0075)\end{array}$ & $\begin{array}{c}-1.5296 * * * \\
(0.0799)\end{array}$ & $\begin{array}{c}-0.2542 * * * \\
(0.0910)\end{array}$ & $\begin{array}{c}-0.0401 * * * \\
(0.0075)\end{array}$ & $\begin{array}{c}-1.5299 * * * \\
(0.0801)\end{array}$ \\
\hline Change in HHI & $\begin{array}{l}-0.0035 \\
(0.0039)\end{array}$ & $\begin{array}{l}-0.0005 \\
(0.0007)\end{array}$ & $\begin{array}{c}0.0148^{* * * *} \\
(0.0039)\end{array}$ & $\begin{array}{l}-0.0035 \\
(0.0039)\end{array}$ & $\begin{array}{l}-0.0006 \\
(0.0007)\end{array}$ & $\begin{array}{c}0.0148 * * * \\
(0.0039)\end{array}$ \\
\hline Constant & $\begin{array}{l}-0.0853 \\
(2.0391) \\
\end{array}$ & & $\begin{array}{c}34.1964 * * * \\
(3.9736) \\
\end{array}$ & $\begin{array}{l}-0.0919 \\
(2.0461) \\
\end{array}$ & & $\begin{array}{c}34.2103^{* * *} \\
(3.9516) \\
\end{array}$ \\
\hline Bidder Fixed Effects & No & & Yes & No & & Yes \\
\hline Failed Bank Fixed Effects & Yes & & Yes & Yes & & Yes \\
\hline Wald Chi-squared & 0.0481 & & & 0.0446 & & \\
\hline Wald $p$-value & 0.8263 & & & 0.8328 & & \\
\hline$\rho$ & 0.0659 & & & 0.0638 & & \\
\hline Auctions & 415 & & & 415 & & \\
\hline Observations & 43656 & & & 43656 & & \\
\hline
\end{tabular}




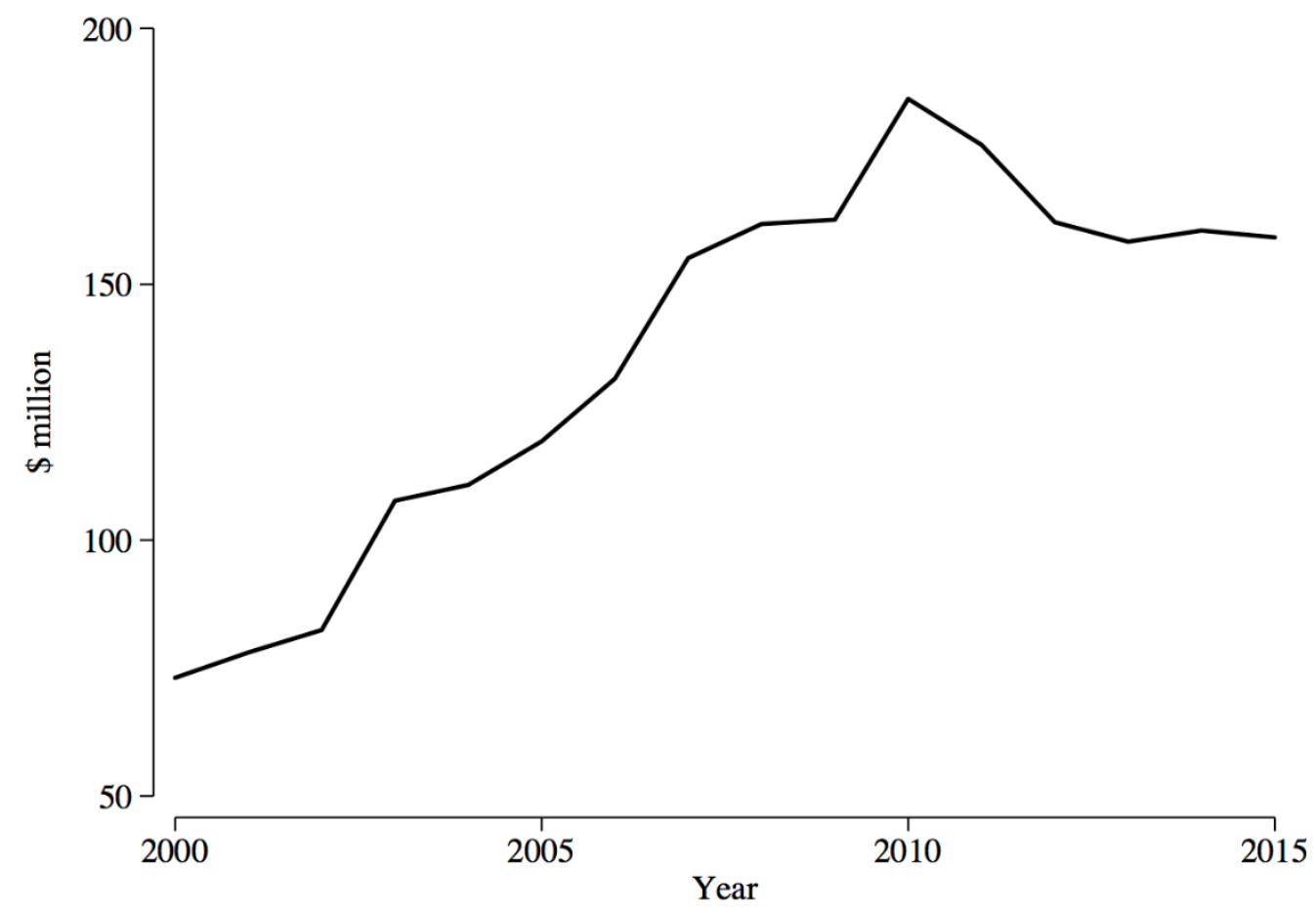

Figure 1. Aggregated Lobbying Expenditures by Banks Satisfying the FDIC Initial Criteria

This figure plots the time series of the aggregate annual lobbying expenditures by all U.S. banks in our sample qualifying according to the FDIC to bid in a failed-bank auction between 2000 and 2015 . The initial criteria include geographic proximity to the failed bank, total assets, and financial health (see Table A.1 for more details). 


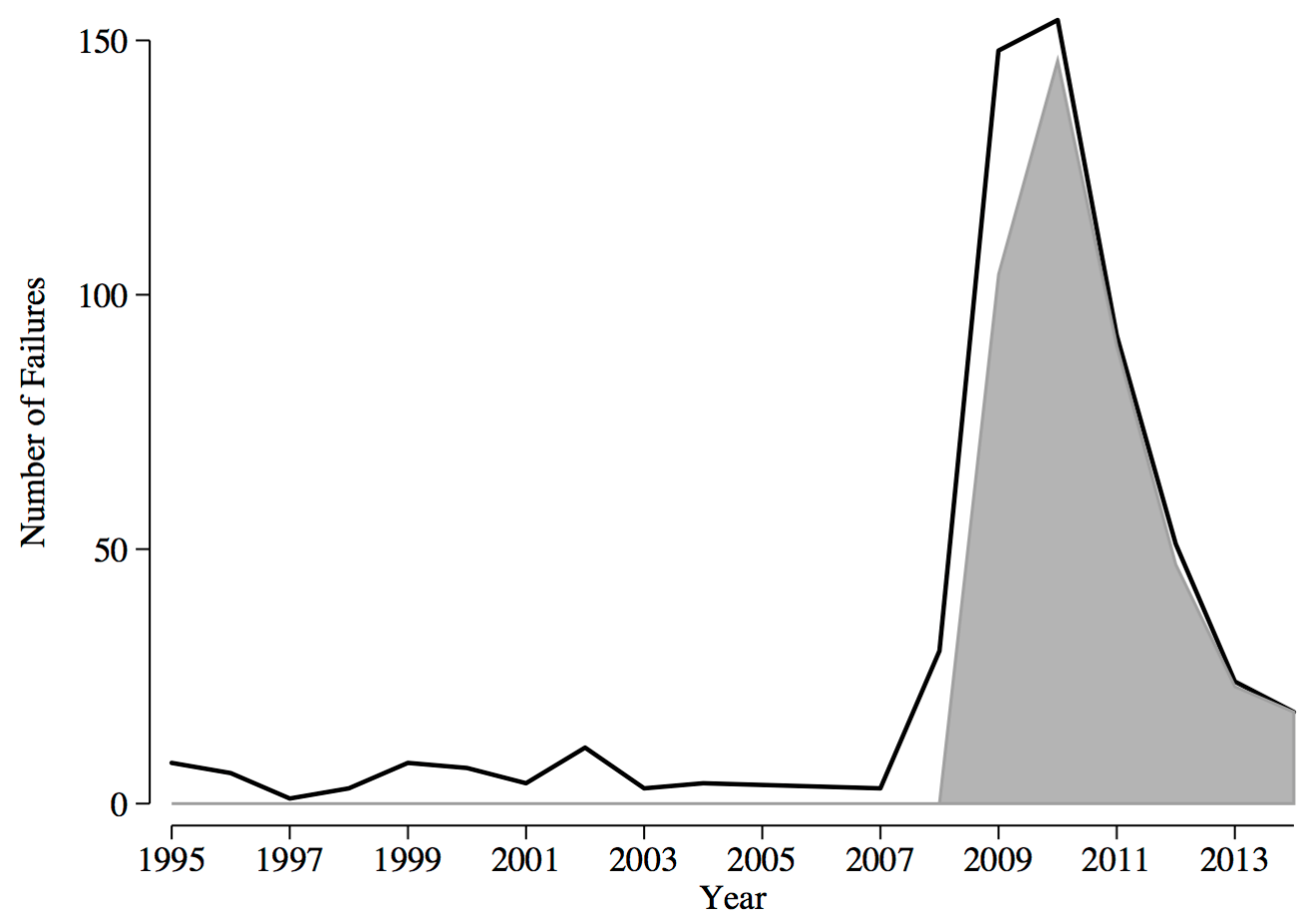

Figure 2. Number of Bank Failures

This figure plots the time series of all bank failures between 1995 and 2014. Data is obtained from the FDIC website: www.fdic.gov/bank/individual/failed/banklist.html. The solid line presents the number of bank failures in each year, excluding assistance transactions. The shaded area presents the sample used in the main analysis. 

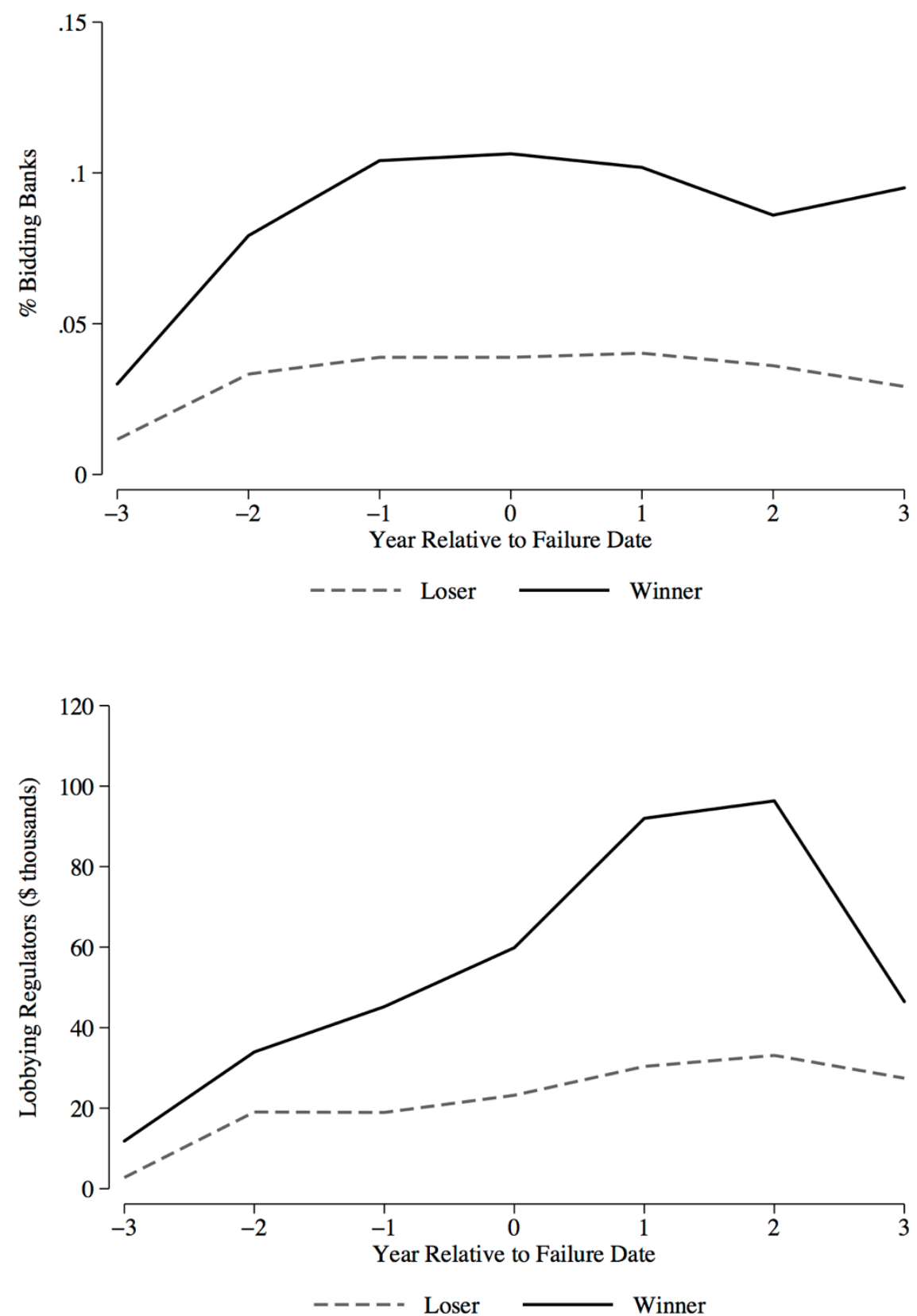

Figure 3. Bidder Lobbying Activities around Bank Failures

The figures show the time series of lobbying activities targeted at banking regulators by all bidding banks in the main analysis during the years around failure dates. Year 0 in the $\mathrm{x}$-axis identifies the calendar year of each bank failure. The figure at the top shows the percentage of bidding banks engage in lobbying targeted at banking regulators, while the figure at the bottom shows the average lobbying expenditures (in $\$$ thousand) on banking regulators. Winner (solid lines) in the auction of a failed bank is the bidding bank that wins the auction and becomes the acquirer of the failed bank. Loser (dashed lines) in the auction is the bidding bank that does not win. 
Failed Bank Assets

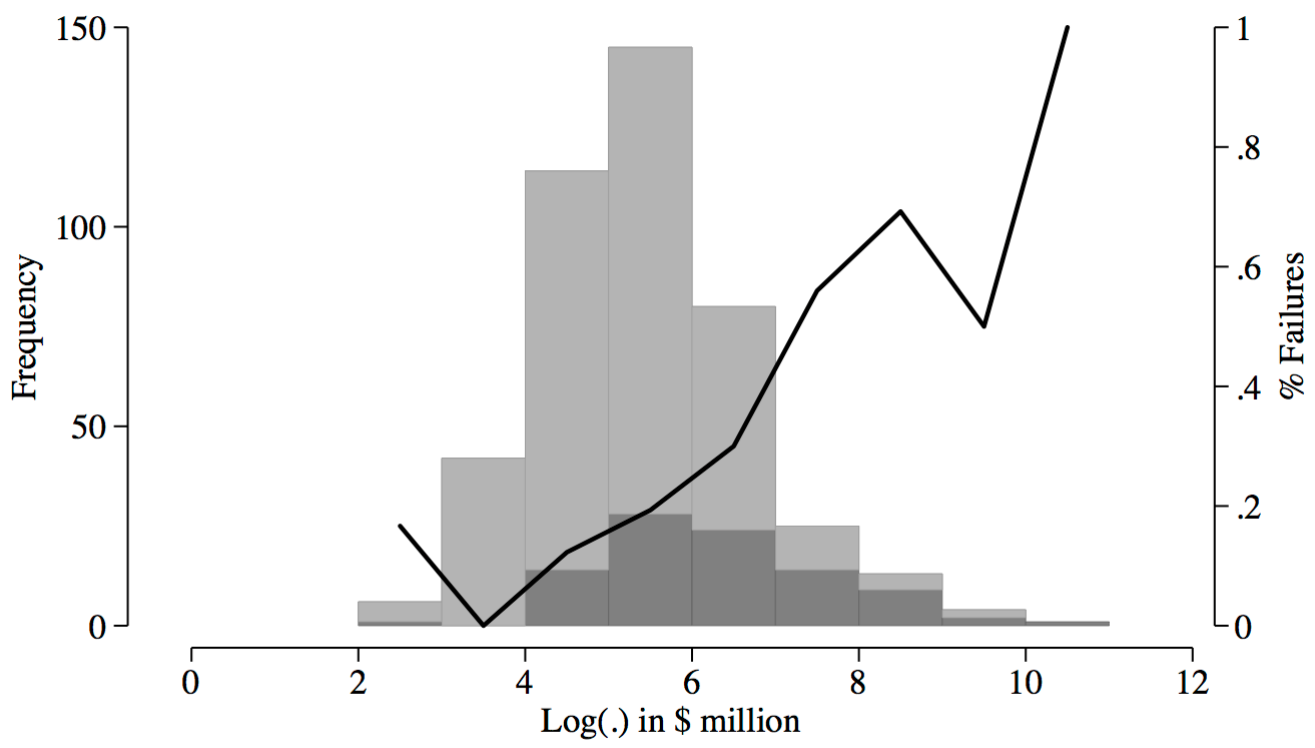

Acquired by Lobbying Banks

All Failed Banks

Acquired by Lobbying Banks (\%)

\section{Figure 4. Histogram of Failed Bank Assets}

The figure shows the histogram of total assets of failed banks. The light shaded bars present the frequencies of bank failures in a corresponding size range (in log-transformation of $\$$ million). The darker shaded bars show the frequencies of bank failures taken over by a lobbying acquirer in a corresponding size range. The solid line depicts the proportion of bank failures with a lobbying acquirer in a corresponding size range. 

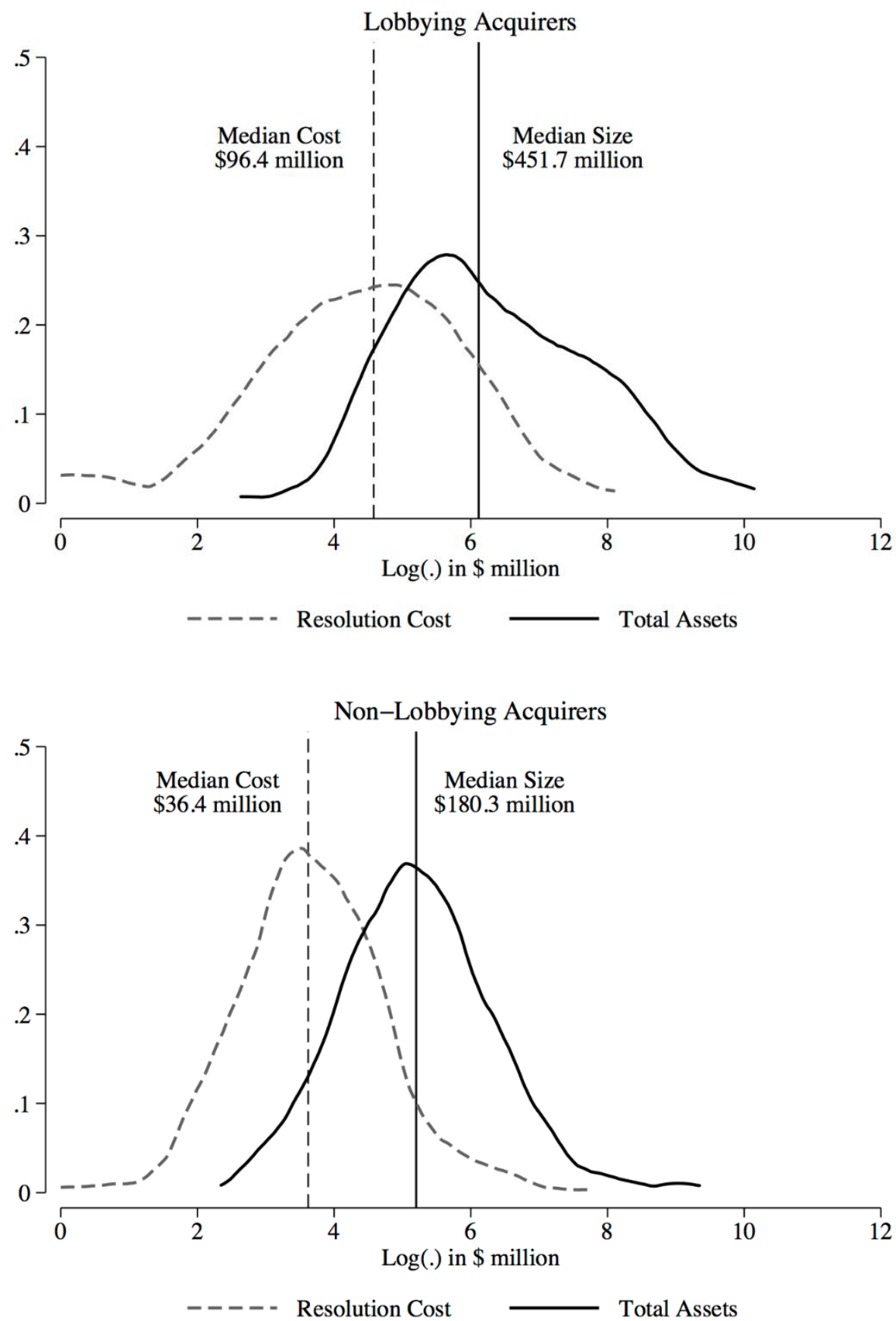

Figure 5. Kernel Density of Failed Bank Assets and Resolution Costs

The figure shows the kernel density functions of total assets of failed banks, split by active lobbying acquirer. Solid lines represent the distributions of failed bank total assets in log value, and dashed lines for resolution costs to the FDIC. Vertical lines indicate the median values in \$ million. The figure at the top depicts the failed banks acquired by banks that have positive lobbying expenditures during the sample period (2007-2014), while the figure at the bottom for failed banks acquired by banks that do not lobby during the sample period. 


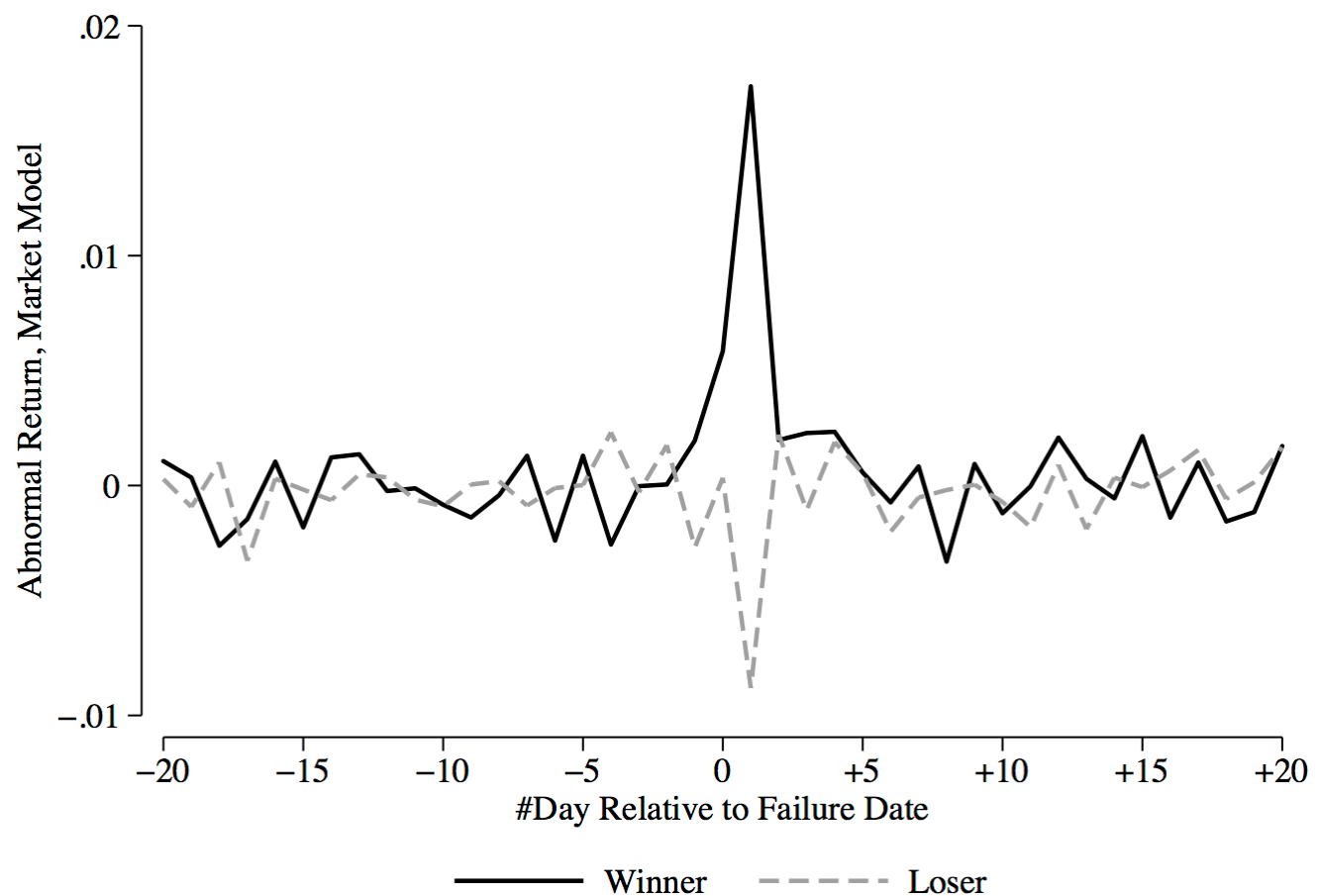

\section{Figure 6. Bidder Abnormal Returns}

The figure shows the average abnormal returns of bidders. Day 0 is the date of the FDIC press release announcing the acquisition, or the first trading day thereafter if the press release was issued on weekend or holiday. The bidder sample consists of bidders in the main sample in which the bidder or its parent bank holding company is a publicly listed firm covered by Compustat/CRSP. Abnormal returns are based on the market model. The solid line represents the average abnormal returns for 201 winner bidders, while the dashed line is for 379 losing bidders. 


\section{Table 1. Auction Sample Construction}

This table presents the construction of the auction sample used in the analysis. The main sample starts with all failed banks in the U.S. between 2007 and 2014, excluding 13 assistance transactions and the outlier Washington Mutual Bank. Assistance transactions via either open bank assistance or providing assistance to the acquirer are rarely used after 1992. Such methods were only used in 5 failed banks belonging to Citigroup on November 23, 2008, and 8 failed banks belonging to Bank of America on January 16, 2009. Payoffs are failed bank resolutions where there is no acquirer and the FDIC pays off all insured deposits. PIs are the acquisitions of only insured deposits of failed banks. The disclosure of failed-bank auctions started from May 2009. In July 9, 2010, RCB Bank and Enterprise Bank \& Trust together purchased Home National Bank. Enterprise Bank \& Trust took over a collection of loans while RCB Bank assumed the rest of assets, including all deposits. The aggregate value of total deposits and total assets (in $\$$ million) are from the last Call Reports of the failed institutions. Aggregated Resolution Cost (in $\$$ million) is the amount disbursed from the Deposit Insurance Fund to cover obligations to insured depositors and the amount estimated (by the FDIC) to be ultimately recovered from the failed bank resolutions.

\begin{tabular}{|c|c|c|c|c|c|}
\hline & Sample & Obs. & $\begin{array}{r}\text { Aggregated } \\
\text { Deposits } \\
\end{array}$ & $\begin{array}{r}\text { Aggregated } \\
\text { Assets } \\
\end{array}$ & $\begin{array}{r}\text { Aggregated } \\
\text { Resolution Cost }\end{array}$ \\
\hline & $\begin{array}{l}\text { All failed banks, excluding } 13 \\
\text { assistance transactions (2007-2014) }\end{array}$ & 509 & 315,774 & 384,831 & 75,045 \\
\hline- & Payoffs (no acquirer) & -26 & 13,888 & 15,901 & 4,467 \\
\hline- & PIs (acquiring insured deposits only) & -13 & 27,673 & 40,341 & 15,284 \\
\hline- & No auction disclosures & -39 & 37,517 & 49,682 & 10,226 \\
\hline- & Two acquirers & -1 & 514 & 585 & 67 \\
\hline & P\&As with auction disclosures & 430 & 236,167 & 278,306 & 44,992 \\
\hline & 1 bidder & 147 & 59,017 & 66,082 & 15,939 \\
\hline & 2 bidders & 81 & 59,076 & 73,229 & 10,805 \\
\hline & 3 bidders & 79 & 40,514 & 47,809 & 8,294 \\
\hline & 4 bidders & 58 & 37,688 & 45,206 & 5,457 \\
\hline & $>4$ bidders & 65 & 39,872 & 45,979 & 4,497 \\
\hline
\end{tabular}




\section{Table 2. Descriptive Statistics}

This table presents descriptive statistics of the main samples used in the analysis. Panel A describes the sample of failed banks. Panel B describes the bidding banks participating in the auctions of failed banks. The variable Resolution Cost in Panel A is expressed as both the dollar amount (in \$ million) and percentage of Total Assets of the failed bank at the time of the failure. Lobbying expenditures are in three forms: (1) indicators that take the value 1 if lobbying expenditures is positive in the year of failures; (2) dollar amount (in \$ thousands) of lobbying expenditures in the year of failures; and (3) log-transformation of the dollar amount in (2). All the other variables are in the quarter prior to the failure dates. See Table A.1 for more details about variable definitions. All variables are winsorized at the $1^{\text {st }}$ and $99^{\text {th }}$ levels.

Panel A. Failed Banks

\begin{tabular}{lrrrrrr}
\hline & & & $25^{\text {th }}$ & & $75^{\text {th }}$ \\
& Obs. & Mean & Std. Dev. & Percentile & Median & Percentile \\
\hline Resolution Cost: & & & & & & \\
Resolution Cost (\$ million) & 430 & 92.86 & 153.06 & 19.58 & 41.15 & 90.98 \\
Resolution Cost (\%) & 430 & 24.17 & 12.54 & 14.83 & 23.5 & 33.05 \\
Net Discount (\%) & 430 & 11.72 & 9.08 & 5.78 & 10.54 & 16.39 \\
Net Discount Differential (\%) & 287 & -1.68 & 8.13 & -4.65 & -1.7 & 0.01 \\
Acquirer Net Discount > Cover Bids & 287 & 0.26 & 0.44 & 0 & 0 & 1 \\
\hline Financial Characteristics: & & & & & & \\
Total Assets (\$million) & 430 & 605.26 & 1421.05 & 98.64 & 203.48 & 453.35 \\
Liquidity Ratio & 374 & 22.24 & 8.77 & 15.21 & 21.22 & 27.03 \\
CRE Loans (\%) & 411 & 10.62 & 8.58 & 4.6 & 8.35 & 14.35 \\
C\&I Loans (\%) & 411 & 25.59 & 17.5 & 12.76 & 23.3 & 32.28 \\
Residential Loans (\%) & 411 & 54.66 & 24.25 & 42.88 & 60.02 & 70.88 \\
Tier 1 Capital Ratio (\%) & 399 & 1.15 & 3.47 & 0.14 & 1.48 & 2.63 \\
NPL Ratio (\%) & 374 & 25.74 & 11.5 & 17.66 & 24.13 & 32.42 \\
OREO Ratio (\%) & 411 & 5.34 & 4.85 & 1.81 & 4.12 & 7.35 \\
Core Deposit (\%) & 374 & 80.57 & 19.27 & 68.87 & 87.39 & 95.97 \\
State Bank & 411 & 0.73 & 0.44 & 0 & 1 & 1 \\
Estimated CAMELS Rating & 411 & 4.97 & 0.16 & 5 & 5 & 5 \\
\hline Acquirer Lobbying Expenditures: & & & & & & \\
Lobbying Regulators >0 & 430 & 0.1 & 0.3 & 0 & 0 & 0 \\
Lobbying Regulators (\$000) & 430 & 52.01 & 219.23 & 0 & 0 & 0 \\
Lobbying Regulators (log) & 430 & 1.23 & 3.77 & 0 & 0 & 0 \\
Active Lobbying & 430 & 0.2 & 0.4 & 0 & 0 & 0 \\
Lobbying > 0 & 430 & 0.16 & 0.36 & 0 & 0 & 0 \\
Lobbying (\$00) & 430 & 123.05 & 368.12 & 0 & 0 & 0 \\
Lobbying (log) & 430 & 2 & 4.71 & 0 & 0 & 0 \\
\hline & & & & & &
\end{tabular}


Panel B. Bidding Banks

\begin{tabular}{|c|c|c|c|c|c|c|}
\hline & Obs. & Mean & Std. Dev. & $\begin{array}{r}25^{\text {th }} \\
\text { Percentile }\end{array}$ & Median & $\begin{array}{r}75^{\text {th }} \\
\text { Percentile }\end{array}$ \\
\hline \multicolumn{7}{|l|}{ Financial Characteristics: } \\
\hline Total Assets (\$million) & 1135 & 8840.63 & 33379.3 & 520.68 & 1466.58 & 3788.68 \\
\hline Liquidity Ratio & 1051 & 25.12 & 11.32 & 17.06 & 23.1 & 31.73 \\
\hline CRE Loans (\%) & 1135 & 14.23 & 9.1 & 7.47 & 12.26 & 18.88 \\
\hline C\&I Loans (\%) & 1135 & 24.99 & 15.54 & 14.68 & 22.51 & 30.99 \\
\hline Residential Loans (\%) & 1135 & 45.67 & 21.57 & 32.68 & 47.88 & 62.14 \\
\hline Tier 1 Capital Ratio & 1088 & 15.78 & 6.96 & 11.83 & 13.88 & 17.09 \\
\hline NPL Ratio & 1051 & 6.18 & 5.3 & 2.51 & 4.87 & 8.11 \\
\hline OREO Ratio & 1135 & 1.04 & 1.13 & 0.21 & 0.65 & 1.43 \\
\hline Core Deposits (\%) & 1051 & 86.3 & 10.76 & 81.94 & 89.4 & 94.19 \\
\hline State Bank & 1135 & 0.73 & 0.45 & 0 & 1 & 1 \\
\hline Estimated CAMELS Rating & 1118 & 1.6 & 0.62 & 1 & 1.5 & 1.5 \\
\hline \multicolumn{7}{|l|}{ Proximity to Failed Banks: } \\
\hline Prospective Bidder & 1051 & 0.61 & 0.49 & 0 & 1 & 1 \\
\hline Distance & 1134 & 5.42 & 1.34 & 4.4 & 5.48 & 6.52 \\
\hline Distance CRE Loans (\%) & 1083 & 23.16 & 19.23 & 8.39 & 17.72 & 33.45 \\
\hline Distance C\&I Loans (\%) & 1083 & 8.9 & 8.14 & 2.83 & 6.54 & 12.43 \\
\hline Distance Residential Loans (\%) & 1083 & 14.87 & 13.63 & 5.18 & 11.54 & 19.75 \\
\hline Change in HHI & 1156 & 1.75 & 9.27 & 0 & 0 & 0.07 \\
\hline \multicolumn{7}{|l|}{ Lobbying Expenditures: } \\
\hline Lobbying Regulators $>0$ & 1156 & 0.06 & 0.25 & 0 & 0 & 0 \\
\hline Lobbying Regulators (\$000) & 1156 & 42.56 & 220.01 & 0 & 0 & 0 \\
\hline Lobbying Regulators (log) & 1156 & 0.83 & 3.17 & 0 & 0 & 0 \\
\hline Active Lobbying & 1156 & 0.18 & 0.39 & 0 & 0 & 0 \\
\hline Lobbying $>0$ & 1156 & 0.12 & 0.32 & 0 & 0 & 0 \\
\hline Lobbying (\$000) & 1156 & 86.72 & 338.77 & 0 & 0 & 0 \\
\hline Lobbying (log) & 1156 & 1.46 & 4.05 & 0 & 0 & 0 \\
\hline
\end{tabular}




\section{Table 3. Winning and Losing Bidders}

This table presents the results of $t$-test with unequal variances of the mean difference between auction winners and losers. All variables on financial characteristics are in the quarter prior to the failure dates. See Table A.1 for more details about variable definitions. All variables are winsorized at the $1^{\text {st }}$ and $99^{\text {th }}$ levels. ${ }^{* * *}, * *$, and $*$ represent statistical significance at $1 \%, 5 \%$, and $10 \%$ levels.

\begin{tabular}{|c|c|c|c|c|c|c|}
\hline & \multicolumn{2}{|c|}{ Winner } & \multicolumn{2}{|c|}{ Loser } & \multicolumn{2}{|c|}{ Winner-Loser } \\
\hline & Obs. & Mean & Obs. & Mean & Difference & $t$-stat. \\
\hline \multicolumn{7}{|l|}{ Financial Characteristics: } \\
\hline Size & 418 & 14.28 & 715 & 14.27 & 0.01 & $(0.09)$ \\
\hline Liquidity Ratio & 389 & 25.64 & 661 & 24.82 & 0.81 & (1.13) \\
\hline CRE Loans (\%) & 418 & 14.98 & 715 & 13.79 & $1.19 * *$ & $(2.19)$ \\
\hline C\&I Loans (\%) & 418 & 24.62 & 715 & 25.19 & -0.57 & $(-0.61)$ \\
\hline Residential Loans (\%) & 418 & 45.83 & 715 & 45.69 & 0.14 & $(0.11)$ \\
\hline Tier 1 Capital Ratio & 406 & 15.96 & 680 & 15.68 & 0.28 & $(0.61)$ \\
\hline NPL Ratio & 389 & 6.14 & 661 & 6.22 & -0.09 & $(-0.24)$ \\
\hline OREO Ratio & 418 & 0.97 & 715 & 1.07 & -0.10 & $(-1.39)$ \\
\hline Core Deposits (\%) & 389 & 84.52 & 661 & 87.38 & $-2.85^{* * * *}$ & $(-3.98)$ \\
\hline State Bank & 418 & 0.70 & 715 & 0.75 & -0.04 & $(-1.61)$ \\
\hline Estimated CAMELS Rating & 411 & 1.61 & 705 & 1.59 & 0.02 & $(0.56)$ \\
\hline \multicolumn{7}{|l|}{ Proximity to Failed Banks: } \\
\hline Prospective Bidder & 397 & 0.55 & 653 & 0.65 & $-0.10 * * *$ & $(-3.20)$ \\
\hline Distance & 414 & 5.25 & 719 & 5.51 & $-0.27^{* * *}$ & $(-3.24)$ \\
\hline Distance CRE Loans (\%) & 400 & 24.01 & 681 & 22.53 & 1.34 & (1.09) \\
\hline Distance C\&I Loans (\%) & 400 & 8.89 & 681 & 8.84 & -0.02 & $(-0.03)$ \\
\hline Distance Residential Loans (\%) & 400 & 15.29 & 681 & 14.52 & 0.65 & $(0.75)$ \\
\hline Change in HHI & 430 & 2.10 & 722 & 1.56 & 0.55 & $(0.91)$ \\
\hline \multicolumn{7}{|l|}{ Lobbying Expenditures: } \\
\hline Lobbying Regulators $>0$ & 430 & 0.10 & 726 & 0.04 & $0.05^{* * *}$ & $(3.30)$ \\
\hline Lobbying Regulators (log) & 430 & 1.23 & 726 & 0.57 & $0.66^{* * *}$ & (3.18) \\
\hline Active Lobbying & 430 & 0.20 & 726 & 0.15 & $0.05^{* *}$ & (2.10) \\
\hline Lobbying $>0$ & 430 & 0.16 & 726 & 0.09 & $0.06^{* * *}$ & (3.09) \\
\hline Lobby $(\log )$ & 430 & 2.00 & 726 & 1.11 & $0.89^{* * *}$ & $(3.40)$ \\
\hline
\end{tabular}




\section{Table 4. Auction Winning Likelihood and Bidder Lobbying: Baseline Results}

This table reports the results of probit regressions. Estimations are the average marginal effects on the likelihood of winning an auction. Control variables include financial characteristics of bidders in the quarter prior to failure dates - Size, Liquidity Ratio, Tier 1 Capital Ratio, NPL Ratio, OREO Ratio, CRE Loans (\%), C\&I Loans (\%), and Residential Loans (\%) - and proximity measures_-Distance and Change in HHI. See Table A.1 for more details about variable definitions. All variables are winsorized at the $1^{\text {st }}$ and $99^{\text {th }}$ levels. Robust standard errors of marginal effects are presented in the parentheses and clustered at the level of the failed bank's state headquarters. $* * *$, **, and * represent statistical significance at $1 \%, 5 \%$, and $10 \%$ levels.

\begin{tabular}{|c|c|c|c|c|}
\hline & (1) & (2) & (3) & (4) \\
\hline & \multicolumn{4}{|c|}{$\operatorname{Pr}($ Win $)$} \\
\hline \multirow[t]{2}{*}{ Lobbying Regulators $>0$} & $0.1858 * * *$ & $0.3425 * * *$ & $0.2640 * * *$ & \\
\hline & $(0.0648)$ & $(0.0648)$ & $(0.0680)$ & \\
\hline \multirow[t]{2}{*}{ Lobbying Regulators } & & & & $0.0208 * * *$ \\
\hline & & & & $(0.0051)$ \\
\hline \multirow[t]{2}{*}{ Size } & & & $0.0529 * *$ & $0.0524 * *$ \\
\hline & & & $(0.0220)$ & $(0.0218)$ \\
\hline \multirow[t]{2}{*}{ Liquidity Ratio } & & & $0.0042 * *$ & $0.0041 * *$ \\
\hline & & & $(0.0020)$ & $(0.0020)$ \\
\hline \multirow[t]{2}{*}{ Tier 1 Capital Ratio } & & & 0.0057 & 0.0058 \\
\hline & & & $(0.0051)$ & $(0.0052)$ \\
\hline \multirow[t]{2}{*}{ NPL Ratio } & & & -0.0080 & -0.0079 \\
\hline & & & $(0.0090)$ & $(0.0090)$ \\
\hline \multirow[t]{2}{*}{ OREO Ratio } & & & -0.0030 & -0.0034 \\
\hline & & & $(0.0470)$ & $(0.0470)$ \\
\hline \multirow[t]{2}{*}{ CRE Loans (\%) } & & & 0.0030 & 0.0031 \\
\hline & & & $(0.0034)$ & $(0.0034)$ \\
\hline \multirow[t]{2}{*}{ C\&I Loans (\%) } & & & -0.0017 & -0.0018 \\
\hline & & & $(0.0027)$ & $(0.0027)$ \\
\hline \multirow[t]{2}{*}{ Residential Loans (\%) } & & & -0.0001 & -0.0001 \\
\hline & & & $(0.0023)$ & $(0.0023)$ \\
\hline \multirow[t]{2}{*}{ Distance } & & & $-0.0725 * * *$ & $-0.0718 * * *$ \\
\hline & & & $(0.0156)$ & $(0.0156)$ \\
\hline \multirow[t]{2}{*}{ Change in $\mathrm{HHI}$} & & & -0.0016 & -0.0016 \\
\hline & & & $(0.0021)$ & $(0.0021)$ \\
\hline Quarter Fixed Effects & Yes & Yes & Yes & Yes \\
\hline Failed Bank State Fixed Effects & Yes & No & No & No \\
\hline Failed Bank Fixed Effects & No & Yes & Yes & Yes \\
\hline Pseudo R-squared & 0.060 & 0.075 & 0.103 & 0.103 \\
\hline Auctions & 422 & 283 & 234 & 234 \\
\hline Observations & 1148 & 1009 & 803 & 803 \\
\hline
\end{tabular}




\section{Table 5. Auction Winning Likelihood and Bidder Lobbying: Instrumental Variable Results}

This table reports the results of IV-probit regressions. $1^{\text {st }}$ Stage columns show OLS estimations and $2^{\text {nd }}$ Stage columns report the average marginal effects on the likelihood of winning an auction. Instrumental variables are an indicator (Lobbying Non-Regulators $>0$ ) and the log-transformation (Lobbying Non-Regulator) of lobbying expenditures targeted at non-banking regulators in the year of the failure. Control variables include financial characteristics of bidders in the quarter prior to failure dates-Size, Liquidity Ratio, Tier 1 Capital Ratio, NPL Ratio, OREO Ratio, CRE Loans (\%), CRE Loans (\%), and Residential Loans (\%) - and proximity measures - Distance and Change in HHI. See Table A.1 for more details about variable definitions. All variables are winsorized at the $1^{\text {st }}$ and $99^{\text {th }} 1$ levels. Robust standard errors of marginal effects are presented in the parentheses and clustered at the level of the failed bank's state headquarters. $* * *, * *$, and * represent statistical significance at $1 \%, 5 \%$, and $10 \%$ levels.

\begin{tabular}{|c|c|c|c|c|}
\hline & \multicolumn{2}{|c|}{ (1) } & \multicolumn{2}{|c|}{ (2) } \\
\hline & $2^{\text {nd }}$ Stage & $1^{\text {st }}$ Stage & $2^{\text {nd }}$ Stage & $1^{\text {st }}$ Stage \\
\hline & $\operatorname{Pr}($ Win $)$ & $\begin{array}{c}\text { Lobbying } \\
\text { Regulators }>0\end{array}$ & $\operatorname{Pr}($ Win $)$ & $\begin{array}{l}\text { Lobbying } \\
\text { Regulators }\end{array}$ \\
\hline Lobbying Regulators $>0$ & $\begin{array}{c}0.2183 * * \\
(0.0949)\end{array}$ & & & \\
\hline Lobbying Non-Regulators $>0$ & & $\begin{array}{c}0.5459 * * * \\
(0.1032)\end{array}$ & & \\
\hline Lobbying Regulators & & & $\begin{array}{c}0.0175 * * \\
(0.0078)\end{array}$ & \\
\hline Lobbying Non-Regulators & & & & $\begin{array}{c}0.6460 * * * \\
(0.1108)\end{array}$ \\
\hline Size & $\begin{array}{c}0.0504 * * \\
(0.0218)\end{array}$ & $\begin{array}{c}0.0086 \\
(0.0089)\end{array}$ & $\begin{array}{c}0.0502 * * \\
(0.0213)\end{array}$ & $\begin{array}{c}0.0541 \\
(0.0891)\end{array}$ \\
\hline Liquidity Ratio & $\begin{array}{c}0.0042 * * \\
(0.0020)\end{array}$ & $\begin{array}{c}0.0003 \\
(0.0009)\end{array}$ & $\begin{array}{l}0.0041 * * \\
(0.0020)\end{array}$ & $\begin{array}{c}0.0105 \\
(0.0114)\end{array}$ \\
\hline Tier 1 Capital Ratio & $\begin{array}{c}0.0057 \\
(0.0052)\end{array}$ & $\begin{array}{c}0.0010 \\
(0.0018)\end{array}$ & $\begin{array}{c}0.0058 \\
(0.0053)\end{array}$ & $\begin{array}{c}0.0157 \\
(0.0248)\end{array}$ \\
\hline NPL Ratio & $\begin{array}{l}-0.0080 \\
(0.0090)\end{array}$ & $\begin{array}{c}0.0012 \\
(0.0036)\end{array}$ & $\begin{array}{l}-0.0079 \\
(0.0090)\end{array}$ & $\begin{array}{l}-0.0036 \\
(0.0460)\end{array}$ \\
\hline OREO Ratio & $\begin{array}{l}-0.0027 \\
(0.0472)\end{array}$ & $\begin{array}{c}0.0023 \\
(0.0098)\end{array}$ & $\begin{array}{l}-0.0029 \\
(0.0472)\end{array}$ & $\begin{array}{c}0.0648 \\
(0.1245)\end{array}$ \\
\hline CRE Loans (\%) & $\begin{array}{c}0.0031 \\
(0.0034)\end{array}$ & $\begin{array}{c}0.0007 \\
(0.0010)\end{array}$ & $\begin{array}{c}0.0031 \\
(0.0034)\end{array}$ & $\begin{array}{c}0.0091 \\
(0.0119)\end{array}$ \\
\hline C\&I Loans (\%) & $\begin{array}{l}-0.0017 \\
(0.0027)\end{array}$ & $\begin{array}{c}0.0006 \\
(0.0009)\end{array}$ & $\begin{array}{l}-0.0018 \\
(0.0027)\end{array}$ & $\begin{array}{c}0.0093 \\
(0.0110)\end{array}$ \\
\hline Residential Loans (\%) & $\begin{array}{c}0.0000 \\
(0.0023)\end{array}$ & $\begin{array}{c}0.0004 \\
(0.0006)\end{array}$ & $\begin{array}{c}0.0000 \\
(0.0023)\end{array}$ & $\begin{array}{c}0.0103 \\
(0.0077)\end{array}$ \\
\hline Distance & $\begin{array}{c}-0.0727 * * * \\
(0.0157)\end{array}$ & $\begin{array}{l}-0.0164 * \\
(0.0097)\end{array}$ & $\begin{array}{c}-0.0722 * * * \\
(0.0155)\end{array}$ & $\begin{array}{c}-0.2452 * * \\
(0.1184)\end{array}$ \\
\hline Change in HHI & $\begin{array}{l}-0.0015 \\
(0.0021) \\
\end{array}$ & $\begin{array}{l}-0.0007 \\
(0.0008) \\
\end{array}$ & $\begin{array}{l}-0.0015 \\
(0.0020) \\
\end{array}$ & $\begin{array}{l}-0.0075 \\
(0.0112) \\
\end{array}$ \\
\hline Quarter Fixed Effects & Yes & Yes & Yes & Yes \\
\hline Failed Bank Fixed Effects & Yes & Yes & Yes & Yes \\
\hline Wald Chi-squared & 0.4161 & & 0.2319 & \\
\hline Wald $p$-value & 0.5189 & & 0.6301 & \\
\hline Auctions & 234 & & 234 & \\
\hline Observations & 803 & & 803 & \\
\hline
\end{tabular}




\section{Table 6. Auction Winning Likelihood and Bidder Lobbying: Alternative Lobbying Measures}

This table reports the results of probit regressions. Estimations are the average marginal effects on the likelihood of winning an auction. Lobbying through Revolving-Door Lobbyists $>0$ is an indicator that takes the value of 1 if the bidding bank hires any revolving-door lobbyists in the year of the failure. Revolvingdoor lobbyists are those who have previously served in any of the relevant banking regulators or in a financial subcommittee of Congress. Lobbying Regulators through Revolving-Door Lobbyists $>0$ is an indicator that takes the value of 1 if the bidding bank hires revolving-door lobbyists to lobby banking regulators. Lobbying Regulators Before $>0$ is an indicator that takes the value of 1 if the bidding bank lobbies banking regulators during a period of eight quarters prior to the failure date. Lobbying Regulators Before is the log 1 plus lobbying expenditures targeted at banking regulators during a period of eight quarters prior to the failure date. Lobbying FDIC $>0$ is an indicator that takes the value of 1 if the bidding bank lobbies the FDIC in the year of failure. Lobbying FDIC is the log of 1 plus lobbying expenditures targeted at the FDIC in the year of failure. Control variables include financial characteristics of bidders in the quarter prior to failure datesSize, Liquidity Ratio, Tier 1 Capital Ratio, NPL Ratio, OREO Ratio, CRE Loans (\%), CRE Loans (\%), and Residential Loans (\%)—and proximity measuresDistance and Change in HHI. See Table A.1 for more details about variable definitions. All variables are winsorized at the $1^{\text {st }}$ and $99^{\text {th }}$ levels. Robust standard errors of marginal effects are presented in the parentheses and clustered at the level of the failed bank's state headquarters. ***, **, and * represent statistical significance at $1 \%, 5 \%$, and $10 \%$ levels.

\section{(1)}

$0.5850 * * *$

(0.0767)

Lobbying Regulators through Revolving-Door Lobbyists $>0$

Lobbying Regulators Before $>0$

Lobbying Regulators Before

Lobbying FDIC $>0$

Lobbying FDIC

Quarter Fixed Effects

Failed Bank Fixed Effects

Pseudo R-squared

Auctions

Observations
(2)

(3)

Pr(Win)

(0.1432)

$0.3085^{* * *}$

(0.0703)

$0.0235 * * *$

(0.0053)

$0.2477 * * *$

(0.0618)

$0.0198 * * *$

(0.0051)

$\begin{array}{cccccc}\text { Yes } & \text { Yes } & \text { Yes } & \text { Yes } & \text { Yes } & \text { Yes } \\ \text { Yes } & \text { Yes } & \text { Yes } & \text { Yes } & \text { Yes } & \text { Yes } \\ 0.121 & 0.121 & 0.107 & 0.108 & 0.098 & 0.098 \\ 234 & 234 & 234 & 234 & 234 & 234 \\ 803 & 803 & 803 & 803 & 803 & 803\end{array}$

$\begin{array}{cccccc}\text { Yes } & \text { Yes } & \text { Yes } & \text { Yes } & \text { Yes } & \text { Yes } \\ \text { Yes } & \text { Yes } & \text { Yes } & \text { Yes } & \text { Yes } & \text { Yes } \\ 0.121 & 0.121 & 0.107 & 0.108 & 0.098 & 0.098 \\ 234 & 234 & 234 & 234 & 234 & 234 \\ 803 & 803 & 803 & 803 & 803 & 803\end{array}$




\section{Table 7. Auction Winning Likelihood and Bidder Lobbying: Auction Competition}

This table reports the results of probit regressions. Estimations are the average marginal effects of Lobbying Regulators (dummy or log-dollar value) on the likelihood of winning an auction in different subsamples. Independent variables are the interaction terms of the indicator (Lobbying Regulators $>0$ ) in columns 1 and 2, or Lobbying Regulators in columns 4 and 5 , with another dummy variable indicating whether the observation is within a certain subsample. In columns 1 and 3 , the sample is split in two parts, whether the auction involves two bidders or strictly more than two bidders. In column 2 and 4 , the sample is split in four parts, whether the auction involves two bidders, three bidders, four bidders, or strictly more than four bidders. We correct estimation and standard errors of marginal effects following Norton, Wang, and Ai (2004). Control variables (unreported) include financial characteristics of bidders in the quarter prior to failure dates-Size, Liquidity Ratio, Tier 1 Capital Ratio, NPL Ratio, OREO Ratio, CRE Loans (\%), C\&I Loans (\%), and Residential Loans (\%)—and proximity measures - Distance and Change in HHI. See Table A.1 for more details about variable definitions. All variables are winsorized at the $1^{\text {st }}$ and $99^{\text {th }}$ levels. Robust standard errors of marginal effects are presented in the parentheses and clustered at the level of the failed bank's state headquarters. $* * *, * *$, and * represent statistical significance at $1 \%, 5 \%$, and $10 \%$ levels.

\begin{tabular}{|c|c|c|c|c|}
\hline & (1) & (2) & (3) & (4) \\
\hline & \multicolumn{2}{|c|}{ Lobbying Regulators $>0$} & \multicolumn{2}{|c|}{ Lobbying Regulators } \\
\hline & \multicolumn{4}{|c|}{$\operatorname{Pr}($ Win $)$} \\
\hline \multirow[t]{2}{*}{ Number of Bidders $=2$} & $0.6799 * *$ & & $0.0544 * *$ & \\
\hline & $(0.2919)$ & & $(0.0222)$ & \\
\hline \multirow[t]{2}{*}{ Number of Bidders $>2$} & $0.1786^{* *}$ & & $0.0142^{* * *}$ & \\
\hline & $(0.0714)$ & & $(0.0051)$ & \\
\hline \multirow[t]{2}{*}{ Number of Bidders $=2$} & & $0.6819 * *$ & & $0.0546 * *$ \\
\hline & & $(0.2916)$ & & $(0.0222)$ \\
\hline \multirow[t]{2}{*}{ Number of Bidders $=3$} & & $0.2748 * *$ & & $0.0205 * *$ \\
\hline & & $(0.1363)$ & & $(0.0102)$ \\
\hline \multirow[t]{2}{*}{ Number of Bidders $=4$} & & $0.2968 * *$ & & $0.0269 * * *$ \\
\hline & & $(0.1341)$ & & $(0.0083)$ \\
\hline \multirow[t]{2}{*}{ Number of Bidders $>4$} & & 0.0941 & & 0.0075 \\
\hline & & $(0.1295)$ & & $(0.0097)$ \\
\hline Quarter Fixed Effects & Yes & Yes & Yes & Yes \\
\hline Failed Bank Fixed Effects & Yes & Yes & Yes & Yes \\
\hline Bidder Controls & Yes & Yes & Yes & Yes \\
\hline Pseudo R-squared & 0.108 & 0.108 & 0.109 & 0.110 \\
\hline Auctions & 234 & 234 & 234 & 234 \\
\hline Observations & 803 & 803 & 803 & 803 \\
\hline
\end{tabular}




\section{Table 8. Comparing Bids}

This table reports the results of regressions of the difference in net discount between the acquirer and the cover bidder. In columns $1-4$, the dependent variable of the OLS regression is Net Discount Differential (\%). In columns 5-8, the dependent variable of the probit regression is Acquirer Net Discount $>$ Cover Bid. The independent variable of interest in columns 1 and 5 is Diff. Lobbying Regulators $>0$, the difference of two indicator variables - Acquirer Lobbying Regulator $>0$ and Cover Bidder Lobbying Regulator $>0$. The independent variable of interest in columns 3 and 7 is Diff. Lobbying Regulators the difference of two continuous variables - Acquirer Lobbying Regulator and Cover Bidder Lobbying Regulator. The independent variable of interest in columns 2 and 6 is Lobbying Regulator $>$ 0 for the acquirer and cover bidder, respectively. The independent variable of interest in columns 4 and 8 is Lobbying Regulators (log-dollar value) for the acquirer and cover bidder, respectively. Bid characteristic controls include two dummies-All Bank \& All Deposits and Loss-Sharing Agreement-for both the winning bids and cover bids. Failed bank control variables include failed bank characteristics at the time of failure-Size, Liquidity Ratio, Tier 1 Capital Ratio, NPL Ratio, OREO Ratio, CRE Loans (\%), C\&I Loans (\%), and Residential Loans (\%). Number of Bidders Fixed Effects are a set of dummy variables indicating the total number of bidders participating in the auction is two, three, etc. See Table A.1 for more details about variable definitions. All variables are winsorized at the $1^{\text {st }}$ and $99^{\text {th }}$ levels. Robust standard errors of marginal effects are presented in the parentheses and clustered at the level of the failed bank's state headquarters. $* * *$, **, and * represent statistical significance at $1 \%, 5 \%$, and $10 \%$ levels.

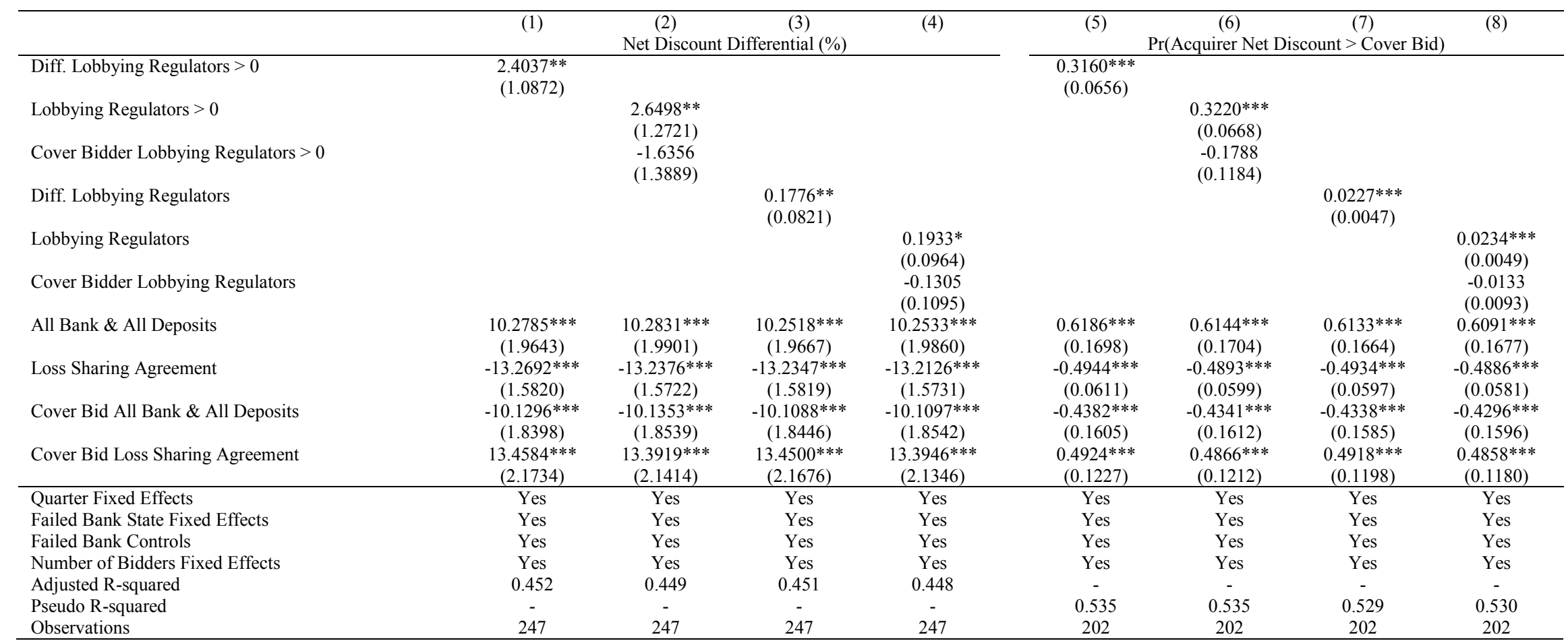




\section{Table 9. Post-Acquisition Efficiency}

This table presents the results from fixed-effects panel regression models. The dimension of the constructed panel is at the joint-bank and quarter levels. Both dependent and independent variables are the weighted average of the acquirer and the failed bank by total assets in the quarters prior to failure dates and then those of acquirers in the quarters after failure dates. All quarters between 2003 and 2015 are included, except for the four quarters starting from the failure quarters. Post-Acquisition is an indicator that takes the value of 1 for the quarters after the failure date. Lobbying Regulators $>0$ and Lobbying Regulators are measured in the year of the failure, are absorbed by Joint Bank Fixed Effects, except for the interaction terms. Joint-bank controls include Size, Liquidity Ratio, Tier 1 Capital Ratio, NPL Ratio, OREO Ratio, CRE Loans (\%), C\&I Loans (\%), and Residential Loans (\%). All variables are winsorized at the $1^{\text {st }}$ and $99^{\text {th }}$ levels. Robust standard errors are presented in the parentheses and clustered at the joint-bank level. ***, $* *$, and * represent statistical significance at $1 \%, 5 \%$, and $10 \%$ levels.

\begin{tabular}{|c|c|c|c|c|}
\hline & $\begin{array}{c}(1) \\
\mathrm{ROA}\end{array}$ & $\begin{array}{c}(2) \\
\mathrm{ROA}\end{array}$ & $\begin{array}{c}(3) \\
\text { Cost Ratio } \\
\end{array}$ & $\begin{array}{c}(4) \\
\text { Cost Ratio } \\
\end{array}$ \\
\hline \multirow[t]{2}{*}{ (Lobbying Regulators $>0$ ) * Post-Acquisition } & $-0.1771 * * *$ & & $0.0473 *$ & \\
\hline & $(0.0272)$ & & $(0.0266)$ & \\
\hline \multirow[t]{2}{*}{ Lobbying Regulators * Post-Acquisition } & & $-0.0142 * * *$ & & $0.0038^{*}$ \\
\hline & & $(0.0021)$ & & $(0.0021)$ \\
\hline \multirow[t]{2}{*}{ Post-Acquisition } & $0.0760 * * *$ & $0.0761 * * *$ & -0.0107 & -0.0108 \\
\hline & $(0.0258)$ & $(0.0258)$ & $(0.0197)$ & $(0.0197)$ \\
\hline \multirow[t]{2}{*}{ Size } & $0.1677 * * *$ & $0.1680 * * *$ & $-0.0990 * * *$ & $-0.0991 * * *$ \\
\hline & $(0.0195)$ & $(0.0196)$ & $(0.0171)$ & $(0.0171)$ \\
\hline \multirow[t]{2}{*}{ Liquidity Ratio } & $-0.0058 * * *$ & $-0.0058 * * *$ & $-0.0017 * *$ & $-0.0017 * *$ \\
\hline & $(0.0008)$ & $(0.0008)$ & $(0.0007)$ & $(0.0007)$ \\
\hline \multirow[t]{2}{*}{ Tier 1 Capital Ratio } & $0.0200 * * *$ & $0.0200 * * *$ & -0.0016 & -0.0016 \\
\hline & $(0.0027)$ & $(0.0027)$ & $(0.0015)$ & $(0.0015)$ \\
\hline \multirow[t]{2}{*}{ NPL Ratio } & $-0.0183 * * *$ & $-0.0183 * * *$ & $0.0046^{* * *}$ & $0.0046 * * *$ \\
\hline & $(0.0022)$ & $(0.0022)$ & $(0.0017)$ & $(0.0017)$ \\
\hline \multirow[t]{2}{*}{ OREO Ratio } & $-0.0163 *$ & $-0.0164 *$ & 0.0071 & 0.0072 \\
\hline & $(0.0094)$ & $(0.0094)$ & $(0.0065)$ & $(0.0065)$ \\
\hline \multirow[t]{2}{*}{ CRE Loans (\%) } & $-0.0023 * * *$ & $-0.0024 * * *$ & $0.0017^{*}$ & $0.0017^{*}$ \\
\hline & $(0.0007)$ & $(0.0007)$ & $(0.0009)$ & $(0.0009)$ \\
\hline \multirow[t]{2}{*}{ C\&I Loans (\%) } & -0.0011 & -0.0011 & $0.0022 *$ & $0.0022 *$ \\
\hline & $(0.0014)$ & $(0.0014)$ & $(0.0013)$ & $(0.0013)$ \\
\hline \multirow[t]{2}{*}{ Residential Loans (\%) } & -0.0015 & -0.0015 & $0.0071 * * *$ & $0.0071 * * *$ \\
\hline & $(0.0013)$ & $(0.0013)$ & $(0.0019)$ & $(0.0019)$ \\
\hline Quarter Fixed Effects & Yes & Yes & Yes & Yes \\
\hline Joint-Bank Fixed Effects & Yes & Yes & Yes & Yes \\
\hline Adjusted R-squared & 0.343 & 0.343 & 0.615 & 0.615 \\
\hline Auctions & 400 & 400 & 400 & 400 \\
\hline Observations & 12935 & 12935 & 12935 & 12935 \\
\hline
\end{tabular}




\section{Table 10. Bidder CAR}

This table presents the results of the stock reaction around failed-bank acquisition announcement dates. CAR $(-1,+1)$ is the three-trading-day cumulative abnormal return around acquisition announcement dates based on the market model. Date 0 is the date of the FDIC press release announcing the acquisition, or the first trading day thereafter if the press release was issued on weekend or holiday. Bidders with less than 100 valid observations in the estimation window $(-245,-42)$ are excluded. In Panel A, the bidder sample consists both the winning bidder- the acquirers-and the losing bidders that have publicly listed parent bank holding company. In Panel B, the sample consists of the winner subsample of Panel A. The regression controls include failed-bank characteristics_-Failed Bank Size and Failed Bank Tier 1 Capital Ratio - and acquirer bank holding company characteristics - Relative Size, ROA, Capital Ratio, and Distance between the acquiring bank and the failed bank. Relative Size is the ratio of failed bank total assets over the book value of bank holding company (BHC total assets) in the last fiscal year end before the failure dates. ROA is Compustat item EBITDA over BHC total assets. Acquirer BHC Capital Ratio is the book leverage - book value of equity over total assets. Failed States only identify California, Georgia, Illinois, and Florida, versus all the others. All variables are winsorized at the $1^{\text {st }}$ and $99^{\text {th }}$ levels. Robust standard errors are presented in the parentheses and clustered at the level of the failed bank's states. ${ }^{* *},{ }^{* *}$, and * represent statistical significance at $1 \%, 5 \%$, and $10 \%$ levels.

Panel A. Bidder bank holding company abnormal returns CAR $(-1,+1)$

\begin{tabular}{lrccrrrr}
\hline & Obs. & Mean & \multicolumn{1}{c}{$t$-stat. } & Std. Dev. & $25^{\text {th }}$ Percentile & Median & $75^{\text {th }}$ Percentile \\
\hline All & 580 & $0.0047^{* *}$ & $(2.7802)$ & 0.0411 & -0.0181 & -0.0005 & 0.0205 \\
Winner & 201 & $0.0206^{* * *}$ & $(5.6526)$ & 0.0518 & -0.011 & 0.0098 & 0.0408 \\
Loser & 379 & $-0.0037^{*}$ & $(-2.3008)$ & 0.0311 & -0.0208 & -0.0048 & 0.0143 \\
\hline Winner-Loser & & $0.0243^{* * *}$ & $(6.1008)$ & & & & \\
\hline
\end{tabular}

Panel B. Winner bank holding company abnormal returns CAR $(-1,+1)$

\begin{tabular}{lcccc}
\hline & $(1)$ & $(2)$ & $(3)$ & $(4)$ \\
& \multicolumn{4}{c}{ Acquirer CAR $(-1,+1)$} \\
\hline Lobbying Regulators $>0$ & $-0.0270^{* *}$ & $-0.0091^{*}$ \\
Lobbying Regulators & $(0.0091)$ & $(0.0034)$ & & \\
& & & $-0.0020^{*}$ & $-0.0007^{* *}$ \\
Controls & & & $(0.0007)$ & $(0.0002)$ \\
Quarter Fixed Effects & No & Yes & No & Yes \\
Failed Bank State Fixed Effects & Yes & Yes & Yes & Yes \\
Adjusted R-squared & Yes & Yes & Yes & Yes \\
Observations & 0.026 & 0.251 & 0.025 & 0.251 \\
& 201 & 198 & 201 & 198 \\
\hline
\end{tabular}

